\title{
Federal Civil Litigation as an Instrument of Police Reform: A Natural Experiment Exploring the Effects of the Floyd Ruling on Stop-and-Frisk Activities in New York City ${ }^{\dagger}$
}

\author{
Michael D. White* \\ Henry F. Fradella** \\ Weston J. Morrow*** \\ Doug Mellom ${ }^{* * * *}$
}

\begin{abstract}
$\dagger \quad$ The authors are aware of the fact that the punctuation of the phrase stop-and-frisk varies considerably by style guide. The Associated Press, for example, calls for the words to be in quotations when used as a subject or object noun phrase, while separating the words with hyphens when used as compound modifier. But even the Associated Press is wildly inconsistent in how their style guide is actually used. See Fev, Stopses and Friskses, HeAdsup Blog: ThORTS And Comments ABOUt EDITING AND THE DESKLy ARTS (Aug. 12, 2013), http://headsuptheblog.blogspot.com/2013/08/stopses-and-friskses.html. For the sake of consistency and readability, we hyphenate the phrase all the time.

* Professor, School of Criminology and Criminal Justice, Arizona State University; Associate Director, Center for Violence Prevention and Community Safety, Arizona State University. Dr. White earned a Ph.D. in criminal justice from Temple University in 1999.

** Professor and Associate Director, School of Criminology and Criminal Justice, Arizona State University. Dr. Fradella earned a master's in forensic science and a law degree from The George Washington University in 1993 and a Ph.D. in justice studies from Arizona State University in 1997.

**** Assistant Professor, Department of Criminal Justice, University of Nevada, Reno. Dr. Morrow earned a Ph.D. in criminology and criminal justice from Arizona State University in 2015.

**** Doctoral student in the School of Criminology and Criminal Justice at Arizona State University. Mr. Mellom earned an M.S. in criminal justice from the University of Wisconsin, Milwaukee.
\end{abstract}


Stop-and-frisk has emerged as a popular crime control tactic in American policing. Though stop-and-frisk has a long, established legal history, the recent experiences in many jurisdictions demonstrate a strong disconnect between principle and practice. Arguably, stop-andfrisk has become the next iteration of a persistent undercurrent in racial injustice in American policing, perhaps best demonstrated by the recent police killings of Eric Garner, Michael Brown, and Freddie Gray-all during stop-and-frisk encounters. Recent events have facilitated a national dialogue on police accountability and police reform, and federal civil litigation has been central to that discussion. Although federal court relief can be pursued through a variety of avenues (most frequently by individuals or class actions under 42 U.S.C. $\$ 1983$ or by the U.S. Department of Justice pursuant to 42 U.S.C. \& 14141), very little research has examined the impact of federal civil litigation on unconstitutional police practices. The current study examines the New York City confluence of racial injustice in policing, misuse of stop-andfrisk by officers, and federal civil litigation designed to precipitate police reform. Authors employ a natural experimental design to conduct a year-to-year comparison of stop-and-frisk activities and outcomes conducted by the NYPD in 2011, during the height of their stop-and-frisk program, and 2014, one year after a federal court deemed the program unconstitutional and ordered reforms. Results show substantial improvement in stop-and-frisk practices following the federal civil litigation, including reduced prevalence and geographic concentration, as well as increased rates of arrest and weapon and contraband seizures. Moreover, crime continued to decline in New York as the NYPD reformed its stop-and-frisk program. Even though racial disparities in those subjected to stops by the NYPD persist, the overall findings show positive progress in New York and highlight the role of federal civil litigation as an instrument of police reform. 


\section{TABLE OF CONTENTS}

I. INTRODUCTION

II. THE ORIGINS AND AUTHORITY OF STOP-AND-FRISK.......................................15

A. From English Common Law to the Uniform Arrest Act ..........................16

B. Terry, Sibron, and Peters.......................................................................18

C. Key Court Cases After 1968.................................................................20

III. STOP-AND-FRISK AND THE UNDERCURRENT OF RACIAL INJUSTICE .................22

A. Racial Issues in Terry v. Ohio ...............................................................23

B. Racial Issues Throughout American Policing............................................25

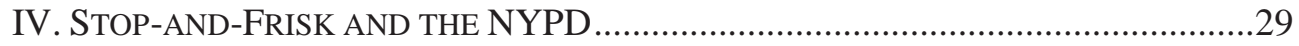

A. Crime, Disorder, and Broken Windows .............................................29

B. Crime Control Benefits.......................................................................33

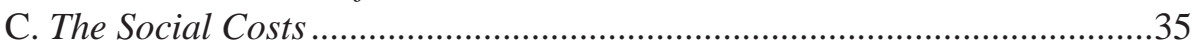

V. Federal Civil Litigation AS AN InStRUment Of Police ReForm ...............37

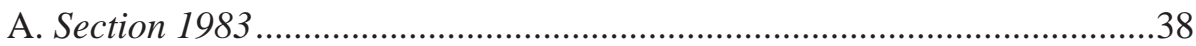

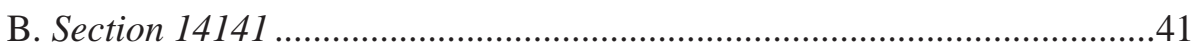

C. Federal Civil Litigation over the NYPD's Stop-and-Frisk Program ........45

D. The Current Study ..................................................................................49

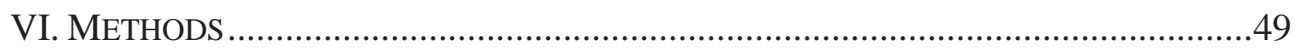

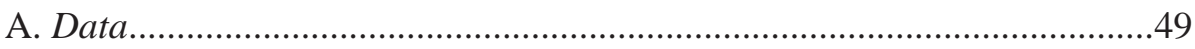

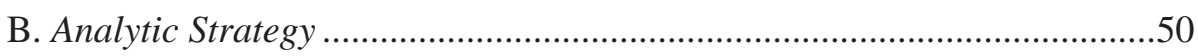

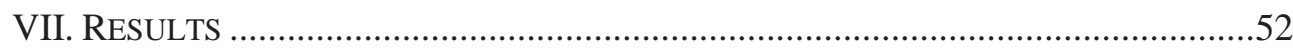

A. Stop Counts and Geographic Concentration ..........................................52

B. Stop Outcomes: Frisks, Searches, Arrests, Weapons and Contraband.....56

C. Stop, Frisk, and Racial Disparities .........................................................58

D. Stop, Frisk, and Crime in New York City ...............................................60

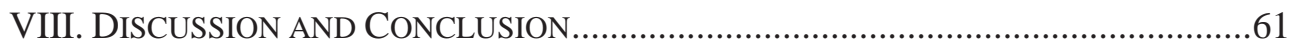

A. Federal Civil Litigation and Police Reform in New York ........................62

B. Larger Lessons for Federal Civil Litigation as an Instrument for Police Reform 


\section{INTRODUCTION}

Police authority to stop, question, and frisk citizens on the street has been a controversial police practice for more than a century. Consider that in 1942, Sam B. Warner, a member of the Interstate Commission on Crime, started his law review article on the Uniform Arrest Act by noting that the law governing police authority to stop, question, frisk, and arrest suspects "illustrates the discrepancy between law in the books and the law in action." "Since the early 1990s, this discrepancy has grown into a highly divisive controversy as a function of a strong disconnect between how police authority to stop, question, and frisk suspects is supposed to work in principle, and how it has actually worked in practice. ${ }^{2}$

On one hand, the practice is grounded in a historical and legal tradition dating back hundreds of years. The basis of a police officer's authority to stop, question, and frisk a suspicious person can be traced back to English common law, as watchmen and private citizens had the authority to "arrest any suspicious nightwalker, and detain him till he give a good account of himself." 3 That common law approach to stop-and-frisk carried over to some United States jurisdictions, although the legal authority for the practice was nebulous at best. ${ }^{4}$ The lack of a clear legal framework for stop-and-frisk led the U.S. Interstate Commission on Crime to draft the Uniform Arrest Act in 1939. ${ }^{5}$ That model statute outlined nine different types of police-citizen contacts including "[q]uestioning and detaining suspects" and "[s]earching suspects for weapons." 6

Litigation over various statutes authorizing stop-and-frisk led the U.S. Supreme Court to formally establish stop-and-frisk as a constitutionally permissible policing tactic in the landmark 1968 decision in Terry v. Ohio. ${ }^{7}$ In the Terry case, the Court held that police may temporarily detain and question a citizen if the officer has reasonable, articulable suspicion that a person may be involved in criminal activity. ${ }^{8}$ The Court also held that officers may superficially search (frisk) a detained person if there is reasonable, articulable suspicion that the person may be armed and dangerous. ${ }^{9}$ Since the Terry ruling, the Court has not only

1 Sam B. Warner, The Uniform Arrest Act, 28 VA. L. ReV. 315, 315 (1942).

2 Michael D. White \& Henry F. Fradella, Stop and Frisk: The Use and Abuse of a Controversial Policing TACTIC (2016).

32 William Hawkins, A Treatise of the Pleas of the Crown 129 (London, 8th ed. 1824) (1716).

Warner, supra note 1, at 319-20.

Id. at 316.

Id. at 317.

Terry v. Ohio, 392 U.S. 1 (1968).

8 Id. at 21-23. See generally John N. Ferdico, Henry F. Fradella \& Christopher D. Totten, Criminal Procedure for the Criminal Justice Professional 306-37 (12th ed. 2015).

9 Terry, 392 U.S. at 23-24; see also FERdiCo, FrAdELLA \& TotTEn, supra note 8, at 337-40. 
consistently reaffirmed the constitutionality of stop-and-frisk, but also expanded officers' authority during such stops. ${ }^{10}$

On the other hand, police use of stop-and-frisk in numerous jurisdictions has strayed dramatically from the principles set forth in Terry and its progeny. ${ }^{11}$ In some cases, police use of stop-and-frisk has been characterized by gross overuse and misuse of the strategy, violations of citizens' Fourth and Fourteenth Amendment rights, strained police-community relationships, low or no police legitimacy, and significant emotional, psychological, and physical consequences experienced by citizens. ${ }^{12}$ The New York City Police Department ("NYPD") epitomizes this story. In 1999, the Office of the New York State Attorney General released a report that examined 175,000 stops and raised serious questions about their constitutionality, as well as racial disparities in those who were stopped. ${ }^{13}$ Allegations of racial discrimination in stops conducted by the NYPD led to two federal lawsuits that mired the NYPD and its stop-and-frisk program in federal court for more than a decade: Daniels v. City of New York ${ }^{14}$ and Floyd v. City of New York. ${ }^{15}$ The controversy came to a head in August 2013, when U.S. District Court Judge Shira Scheindlin ruled that the NYPD's stop-and-frisk program was unconstitutional. ${ }^{16}$

Allegations of racial discrimination in Terry stops have not been limited to New York. In November 2010, the American Civil Liberties Union (ACLU) of Pennsylvania filed a lawsuit in federal court alleging that the Philadelphia Police

10 See, e.g., Brown v. Texas, 443 U.S. 47 (1979); United States v. Mendenhall, 446 U.S. 544 (1980); Michigan v. Long, 463 U.S. 1032 (1983).

11 See generally White \& FrAdella, supra note 2, passim.

12 Id. See also Jeffrey Bellin, The Inverse Relationship between the Constitutionality and Effectiveness of New York City "Stop-and-Frisk," 94 B.U. L. REV. 1495 (2014); Bennett Capers, Rethinking the Fourth Amendment: Race, Citizenship, and the Equality Principle, 46 HARV. C.R.C.L. L. REV. 1 (2011); David A. Harris, Frisking Every Suspect: The Withering of Terry, 28 U.C. Davis L. ReV. 1 (1994); Lewis R. Katz, Terry v. Ohio at Thirty-Five: A Revisionist View, 74 Miss. L.J. 423 (2004); Tracey Maclin, Terry v. Ohio's Fourth Amendment Legacy: Black Men and Police Discretion, 72 St. John's L. ReV. 1271 (1998); Thomas B. McAffee, Setting Us Up for Disaster: The Supreme Court's Decision in Terry v. Ohio, 12 NEV. L.J. 609 (2012).

13 Eliot Spitzer, The New York City Police Department's “Stop-And-Frisk” Practices: A Report to the People of the State of New York from the Office of the Attorney General (1999), http://www.oag.state.ny.us/sites/default/files/pdfs/bureaus/civil_rights/stp_frsk.pdf.

14 Complaint, Daniels v. City of New York, 1:99-cv-01695-SAS (S.D.N.Y. Mar. 8, 1999); see also Daniels v. City of New York, 138 F. Supp. 2d 562 (S.D.N.Y. 2001).

15 Complaint and Demand for Jury Trial, Floyd v. City of New York, 08-cv-01034-SAS (S.D.N.Y. Jan. 31, 2008), http://ccrjustice.org/files/Floyd_Complaint_08.01.31.pdf; see also Floyd v. City of New York, 959 F. Supp. 2d 540 (S.D.N.Y. 2013); id. at 668 (S.D.N.Y. 2013), stay granted sub nom Ligon v. City of New York, 538 Fed. Appx. 101 (2d Cir. 2013), vacated in part by 743 F.3d 362 (2d Cir. 2014).

16 Floyd, 959 F. Supp. 2d at 540. 
Department was engaged in widespread racial profiling. ${ }^{17}$ A report of the ACLU of New Jersey examined stop-and-frisk activities of the Newark Police Department during the last half of 2013 and concluded: "Newark police officers use stop-andfrisk with troubling frequency. . . . Black Newarkers bear the disproportionate brunt of stop-and-frisks. . . . [and] [t]he majority of people stopped [75\%] are innocent."18 Similar stories have unfolded in Detroit, Michigan; Chicago, Illinois; Miami Gardens, Florida; New Orleans, Louisiana; and Pittsburgh, Pennsylvania, just to name a few of the more prominent examples.

The cases of Eric Garner in New York City, Michael Brown in Ferguson, Missouri, and Freddie Gray in Baltimore, Maryland demonstrate the severe and long-lasting consequences of mass stop-and-frisk programs: Garner, Brown, and Gray died during encounters with the police that began as Terry stops. Their deaths, among others, grabbed national headlines, produced widespread public protest and civil disorder, led to a White House-driven initiative for police reform, and fostered larger discussions about the mechanisms for responding to and eliminating widespread racially discriminatory police practices-including federal civil litigation. ${ }^{19}$

Despite the controversy surrounding its stop-and-frisk program-and the federal civil litigation it generated (the Daniels and Floyd cases) - NYPD officers conducted more than 685,000 stops in 2011, most of which affected New Yorkers from racial and ethnic minority backgrounds. ${ }^{20}$ In the year following the Floyd ruling in August 2013 (when the program was deemed unconstitutional by the federal court), newly-elected mayor William de Blasio dropped the City's appeal of the ruling, appointed William Bratton as the new Police Commissioner, and began working with Commissioner Bratton to implement the remedies ordered in Judge Scheindlin's ruling. ${ }^{21}$ The recent developments in the NYPD stop-and-frisk case allow the authors to employ a natural experimental design to assess the impact

17 Complaint, Bailey v. City of Philadelphia, No. 210CV05952, 2010 WL 4662865 (E.D. Pa. Nov. 4, 2010), http://www.aclupa.org/download_file/view_inline/669/198/; see also Settlement Agreement, Class Certification \& Consent Decree, Bailey v. City of Philadelphia, No. 10-5952 (E.D. Pa. June 21, 2011), http://www.aclupa.org/download_file/view_inline/744/198/.

18 Udi Ofer \& Ari Rosmarin, Am. Civil Liberties Union of N.J., Stop-And-Frisk: A First LOOK 5 (2014), https://www.aclu-nj.org/files/8113/9333/6064/2014_02_25_nwksnf.pdf.

19 See President's Task Force on 21st Century Policing, Final Report of the President's TAsk Force ON 21st Century Policing (2015), http://www.cops.usdoj.gov/pdf/taskforce/TaskForce_FinalReport.pdf.

20 Stop-and-Frisk Data, N.Y. CiviL LiBERTIES UnION, http://www.nyclu.org/content/stop-andfrisk-data (last visited Aug. 23, 2016); see also N.Y. POLICE DEP'T, STOP, QUESTION AND FRISK REPORT DATABASE [hereinafter NYPD STOP-AND-FRISK DATABASE], http://www.nyc.gov/html/nypd/html/analysis_and_planning/stop_question_and_frisk_report.shtml (last visited Aug. 23, 2016).

21 Benjamin Weiser \& Joseph Goldstein, Mayor Says New York City Will Settle Suits on Stopand-Frisk Tactics, N.Y. TIMES (Jan. 30, 2014), http://www.nytimes.com/2014/01/31/nyregion/deblasio-stop-and-frisk.html. 
of the federal civil litigation on stop-and-frisks in New York during two years: in 2011, when the program was at its height, and in 2014, one year after the Floyd ruling. To do so, we employ descriptive statistical analyses of NYPD stop-andfrisk data to explore changes in prevalence, geographic concentration, outcomes (e.g., searches, arrests, weapons, and contraband seized), and racial disparities among persons stopped. We also examine crime trends in New York through 2014 to assess whether changes in stop-and-frisk may have affected the NYPD's ability to fight crime. These analyses allow us to draw inferences about the impact of the Floyd ruling on stop-and-frisk practices in New York City. And given the dearth of empirical research in this area, the current study also offers broader insights on the potential for federal civil litigation to serve as an effective instrument of police reform.

Part II examines the origins of stop-and-frisk, as well as the relevant court rulings that have shaped officers' authority to engage in temporary detention, questioning, and frisking of citizens. Part III discusses the persistent undercurrent of racial injustice in American policing, and highlights the important context this undercurrent provides for considering the impact of police use of Terry stops as a mass crime-control strategy. Part IV tells the New York story, where the undercurrent of racial injustice, stop-and-frisk, and federal civil litigation have collided for a period of more than two decades. Part $\mathrm{V}$ provides an overview of the two primary mechanisms by which civil litigation in federal court can be employed as an instrument of police reform under 42 U.S.C. § 1983 and 42 U.S.C. $\S 14141$. Part VI describes the methods employed by the authors in the current study and Part VII details the results of the year-to-year comparison of stop-andfrisk activities and outcomes. Part VIII discusses the implications of the results for police reform in New York and highlights the broader role of federal court litigation as an instrument of police reform in 21st century policing.

\section{THE ORIGINS AND AUTHORITY OF STOP-AND-FRISK ${ }^{22}$}

A law enforcement officer's legal authority to detain and question a suspicious person dates back to the common law of England. English common law had very strict rules governing formal arrests. ${ }^{23}$ Legal proscriptions on investigation of crime, however, were significantly more lax.

22 Portions of Part II are adapted from White \& FrADELLA, supra note 2, at ch. 3.

23 John A. Ronayne, The Right to Investigate and New York's "Stop-and-Frisk” Law, 33 FordHAM L. REV. 211 (1964). 


\section{A. From English Common Law to the Uniform Arrest Act}

English constables and "watchmen" were permitted to detain "nightwalkers"-suspicious people encountered at night. ${ }^{24}$ Indeed, according to Sir Matthew Hale's treatise on English common law, those on the night watch could legally "arrest such as pass by until the morning, and if no suspicion, they are then to be delivered [released], and if suspicion be touching them, they shall be delivered to the sheriff." 25 Even private citizens had the authority to detain and question suspicious "night-walkers.",

Until 1939, there was considerable variation in how U.S. law handled policeinitiated contacts with citizens that did not reach the level of arrest. In some states, it was unclear if American common law, borrowing from its English antecedents, conferred a right to detain and question suspects when the requirements for a full arrest were clearly absent. ${ }^{27}$ In other jurisdictions, the right to detain and question suspects was conferred on police by state statute or by municipal ordinance. ${ }^{28}$ In these states, detentions for questioning "were generally left to the discretion of individual officers and were not subject to constitutional protections or judicial oversight." 29 Inconsistency in state law came to be viewed as "entirely inadequate to meet the modern needs for questioning and detaining suspects.",30

In 1939, the Interstate Commission on Crime authorized a study to examine how arrests were made across the United States. The study examined the feasibility of creating a model law that states could adopt to harmonize arrest practices across the country and to bring the actions of police into alignment with constitutional standards. ${ }^{31}$ Once drafted, that model law became known as the Uniform Arrest Act. Its provisions dealt with nine types of police-initiated contacts with citizens, the first two of which were "[q]uestioning and detaining suspects" and "[s]earching suspects for weapons." 32 Section 2 of the Uniform Arrest Act provided: "A peace officer may stop any person abroad whom he has reasonable ground to suspect is committing, has committed or is about to commit a crime . . . . The total period of detention provided for by this section shall not exceed two hours." ${ }^{\text {,3 }}$ Additionally, Section 3 of the Act stated that an officer was

24 Id. at 214

252 Matthew Hale, The History of the Pleas of the Crown 96 (Philadelphia, Robert H. Small 1847); see also Lawrence v. Hedger, 3 Taunt. 14, 128 Eng. Rep. 6 (C.P. 1810).

26 HAWKINS, supra note 3, at 129.

27 Warner, supra note 1, at 319-20.

28 Id. at 319 (citing 1932 MASs. GEN. LAws c. 41, § 98; 1926 N.H. Pub. Laws c. 363, § 12).

29 Ferdico, Fradella \& Totten, supra note 8, at 308.

30 Warner, supra note 1 , at 317.

31 Id. at 316-17.

32 Id. at 317.

33 Id. at 320-21. 
permitted to conduct a "search for a dangerous weapon ... . whenever he has reasonable ground to believe [a person stopped or detained for questioning] . . . possesses a dangerous weapon.",34

In 1941, the legislatures of New Hampshire and Rhode Island adopted the Uniform Arrest Act as the laws of their states. ${ }^{35}$ Delaware followed suit in $1951 .^{36}$ Other states enacted statutes authorizing stop-and-frisk practices that were not consistent with the Uniform Arrest Act. ${ }^{37}$ As a consequence, considerable variation persisted across states with regard to stop-and-frisk authority. ${ }^{38}$ Prompted by the need to clarify the scope of permissible conduct during stop-andfrisk procedures (and, perhaps, concerns about how vagrancy and loitering laws contributed to police infringements on constitutionally protected liberty interests), the U.S. Supreme Court issues three landmark rulings in 1968 that set federal constitutional benchmarks for stop-and-frisk within the framework of the Fourth Amendment: Terry v. Ohio ${ }^{39}$ and the companion cases of Sibron v. New York and Peters v. New York. ${ }^{40}$ In the interest of brevity, the next section summarizes only the key facts and holdings of these cases. ${ }^{41}$

34 Id. at 325.

351941 N.H. Laws 242, ch. 163 (codified as amended at N.H. Rev. STAT. AnN. §§ 594:1594:23 (1955)); 1941 R.I. Pub. Laws 21, ch. 982 (codified as amended at R.I. GEN. LAws ANN. §§ 12-7-1 to 12-7-17 (1956)).

3648 Del. Laws 769, ch. 304 (1951) (codified as amended in Del. Code AnN. tit. 11, §§ 1901-1912 (1953)).

37 Ronayne, supra note 23, at 215.

38 It should be noted that laws against vagrancy and loitering exacerbated the problems attendant to unclear stop-and-frisk authority. Indeed, vagrancy and loitering laws blurred suspicion with criminal conduct by permitting the police to make arrests - and searches incident to arrestwhenever someone seemed out-of-place or presented as an "undesirable" in a particular location. See Caleb Foote, Vagrancy-Type Law and Its Administration, 104 U. PA. L. REV. 603, 604 (1956).

It is important to note that two quite different kinds of suspicion are involved. The alleged vagrant may be suspected of past criminality, the arrest for vagrancy offering the opportunity to investigate whether the suspect is wanted in another jurisdiction or has committed other crimes. On the other hand, the suspicion may be of future criminality, the inference being that purposeful poverty is likely to lead to other crimes unless the state steps in.

Id. at 625 (footnote omitted). In other words, much of the crime-prevention work accomplished by modern stop-and-frisk procedures used to be accomplished by vagrancy and loitering law arrests. Perhaps it is therefore unsurprising that within four years of the Terry, Sibron, and Peters stop-andfrisk triumvirate, the U.S. Supreme Court invalidated a vagrancy ordinance on vagueness grounds. See Papachristou v. City of Jacksonville, 405 U.S. 156 (1972).

39392 U.S. 1 (1968).

40392 U.S. 40 (1968).

41 For a more detailed and in-depth analysis of the facts, holdings, rationale, and impact of these important cases, see WHITE \& FRADELLA, supra note 2, at ch. 3. 


\section{B. Terry, Sibron, and Peters}

In Terry, Detective Martin McFadden testified that he observed two men while on patrol. The Court summarized McFadden's observations as follows:

He saw one of the men leave the other one and walk southwest on Huron Road, past some stores. The man paused for a moment and looked in a store window, then walked on a short distance, turned around and walked back toward the corner, pausing once again to look in the same store window. He rejoined his companion at the corner, and the two conferred briefly. Then the second man went through the same series of motions, strolling down Huron Road, looking in the same window, walking on a short distance, turning back, peering in the store window again, and returning to confer with the first man at the corner. The two men repeated this ritual alternately between five and six times apiece-in all, roughly a dozen trips. At one point, while the two were standing together on the corner, a third man approached them and engaged them briefly in conversation. This man then left the two others and walked west on Euclid Avenue. Chilton and Terry resumed their measured pacing, peering, and conferring. After this had gone on for 10 to 12 minutes, the two men walked off together, heading west on Euclid Avenue, following the path taken earlier by the third man. ${ }^{42}$

McFadden's observations led him to suspect that the men were planning to commit a robbery in the store. He therefore approached the men and began to question them. Fearing that they might be armed, he patted them down and recovered a revolver on two of the men. McFadden arrested the men for illegal possession of the firearms.

In upholding their convictions, the U.S. Supreme Court made it clear that the Fourth Amendment applies to stop-and-frisk activities. ${ }^{43}$ But "[i]nstead of applying the probable cause standard to stops-and-frisks, the Court applied the fundamental test of the Fourth Amendment: the reasonableness under all the circumstances of the particular governmental invasion of a citizen's personal security." 44 In deciding to analyze the reasonableness of Officer McFadden's

42 Terry, 392 U.S. at 6.

43 Id. at 8, 10, 16-27. Notably, the majority decision in Terry did not clearly distinguish the stop from the frisk. See id. at 10-12. Justice Harlan's concurring opinion did so and clarified that a stop is distinct from an arrest and a frisk is different from a search, even though the Fourth Amendment applies to both police activities. Terry, 392 U.S. at 31-34 (Harlan, J., concurring). Subsequent cases adopted his formulation. See John Q. Barrett, Deciding the Stop and Frisk Cases: A Look Inside the Supreme Court's Conference, 72 ST. JoHn's L. REV. 749, 813 (1998).

44 Ferdico, Fradella \& TotTen, supra note 8, at 309. 
conduct, the Court approved a line of inquiry that is distinct from questions of probable cause. Indeed, the Court analyzed the "reasonableness of Officer McFadden's conduct as a general proposition" by balancing "the need to search [or seize] against the invasion which the search [or seizure] entails." ${ }^{\text {"S }}$ Moreover, the Court maintained that this balancing test depends on whether a law enforcement officer can "point to specific and articulable facts which, taken together with rational inferences from those facts, reasonably warrant that intrusion." 46 The Court then applied a similar balancing test to assess the reasonableness of McFadden's search for weapons. In doing so, the Court found the search to be permissible under the Fourth Amendment in large part because of its limited nature - namely the "pat down" of the men's outer clothing for weapons: "He did not conduct a general exploratory search for whatever evidence of criminal activity he might find." 47

In Sibron, the defendant was convicted of the unlawful possession of heroin. Over the course of several hours, a police officer observed the defendant talking with "six or eight persons whom he (Patrolman Martin) knew from past experience to be narcotics addicts." 48 The officer did not hear any of the conversations, nor did anyone ever pass anything to the defendant during these conversations. Nonetheless, the officer subsequently approached Sibron and said, "You know what I am after," prompting Sibron to reach into his pocket. That action, in turn, caused the officer to reach into Sibron's pocket and retrieve "several glassine envelopes" that contained heroin. ${ }^{49}$ The U.S. Supreme Court overturned Sibron's conviction on the grounds that the officer's initial stop was not supported by reasonable suspicion that Sibron was involved in any criminal activity. So far as the officer knew, 'they might indeed 'have been talking about the World Series.' The inference that persons who talk to narcotics addicts are engaged in the criminal traffic in narcotics is simply not the sort of reasonable inference required to support an intrusion by the police upon an individual's personal security." 50 Moreover, the Court determined that the officer lacked reasonable suspicion that Sibron was armed and dangerous. In fact, the Court reasoned that the officer's "opening statement to Sibron-'You know what I am after'-made it abundantly clear that he sought narcotics" and did not believe that Sibron was reaching for a weapon. ${ }^{51}$

46

47

48

$50 \quad$ Id. at 62.

51 Id. at 64 .

Id. at 21.

Id. at 30.

d.

Terry, 392 U.S. at 20-21.

Sibron, 392 U.S. at 45. 
In Peters, an off-duty police officer heard strange noises outside his apartment door. He investigated and observed two men he had never seen before "tiptoeing" out of the apartment building in which the officer had lived for 12 years. "Believing that he had happened upon the two men in the course of an attempted burglary," the officer "opened his door, entered the hallway and slammed the door loudly behind him. This precipitated a flight down the stairs on the part of the two men, and [the officer] gave chase." ${ }^{52}$ The officer patted down the men and found burglar's tools. The Court affirmed Peters' conviction because the officer had probable cause to believe the men were involved in an attempted burglary. In light of the existence of probable cause to arrest, the search of Peters could be justified as a search incident to arrest - a more complete search than the limited frisk/patdown for weapons authorized under Terry. ${ }^{53}$

\section{Key Court Cases After 1968}

Terry v. Ohio established the legal parameters for stop-and-frisk in the United States. The Supreme Court revisited stop-and-frisk just over a decade later. In two cases, Brown V. Texas ${ }^{54}$ and Ybarra v. Illinois, ${ }^{55}$ the Court invalidated police actions and reinforced the narrow authority granted under Terry. By the 1980s, however, courts began to interpret Terry as providing significant leeway to law enforcement officers to conduct stops. Additionally, the U.S. Supreme Court directed the lower courts to assess the validity of stops based on "the whole picture" - or what came to be known as the "totality of the circumstances." 56 Perhaps more importantly, the Court told lower courts to defer to the professional judgment and experience of police when assessing the totality of the circumstances. $^{57}$

Throughout the 1980s, the U.S. Supreme Court exempted several classes of stops from the usual requirements of Terry. For example, in United States v. Mendenhall, the Court ruled that a stop had not occurred when federal agents approached the defendant in the open concourse area of an airport. ${ }^{58}$ Because the

52 Id. at 48-49 (footnotes omitted).

53 Id. at 66.

54443 U.S. 47 (1979).

55444 U.S. 85 (1979).

56 United States v. Cortez, 449 U.S. 411, 417 (1981).

57 Id. at 421-22 (emphasizing that the relevant line of inquiry in the case was "whether, based upon the whole picture, they, as experienced Border Patrol officers, could reasonably surmise that the particular vehicle they stopped was engaged in criminal activity"). For an analysis of how deference to police experience factors into the reasonable suspicion standard, see David A. Harris, Factors for Reasonable Suspicion: When Black and Poor Means Stopped and Frisked, 69 IND. L.J. 659, 666 (1994).

58 United States v. Mendenhall, 446 U.S. 544 (1980). 
agents neither wore uniforms nor displayed weapons, and because they requested - but did not demand - to see the defendant's ticket and identification, the Court reasoned that the encounter did not constitute a stop that qualified as a seizure for Fourth Amendment purposes, but rather a voluntary and cooperative encounter because at no time should a reasonable person in the defendant's situation have ever felt that she could not leave. ${ }^{59}$ Then, in I.N.S. v. Delgado, the "free to leave" test morphed into something even more restrictive on personal liberty: free to continue working and moving about a factory while armed agents wearing badges roamed the premises questioning people about their immigration status. ${ }^{60}$ The Court further narrowed Terry in Florida v. Bostick when it clarified that law enforcement officers have the authority to stop and ask basic investigatory questions - including requests to examine identification or to search luggage of bus passengers - without there being a seizure for Fourth Amendment purposes "as long as the police do not convey a message that compliance with their requests is required." 61 In short, Bostick all but abandoned Mendenhall's free-to-leave test by changing the inquiry to one of coercive police tactics through shows of authority.

In other cases, the U.S. Supreme Court extended the authority of police to conduct frisks. Consider that in Michigan v. Long, the Court permitted the police to conduct a brief search of the passenger compartment of a car to look for hidden weapons. $^{62}$

Perhaps most importantly, the Court has partially retreated from Sibron's holding that reasonable suspicion needed to be based on more than just hunches. In Alabama v. White, the Court upheld a stop of a vehicle based on an anonymous tip even though there was no indication of the reliability of the tip. ${ }^{63}$ Michigan Department of State Police v. Sitz authorized sobriety checkpoints at which police stopped drivers without any particularized suspicion of driving-while-impaired. ${ }^{64}$ Vernonia School District 47J v. Acton upheld random (i.e., suspicionless) drug testing of student athletes, ${ }^{65}$ and Board of Education of Independent School Dist.

59 Id. at $554-55$.

60 I.N.S. v. Delgado, 466 U.S. 210 (1984).

61 Florida v. Bostick, 501 U.S. 429, 435 (1991).

62 Michigan v. Long, 463 U.S. 1032, 1035 (1983).

63 Alabama v. White, 496 U.S. 325, 329 (1990).

64 Mich. Dep’t of State Police v. Sitz, 496 U.S. 444, 447 (1990). City of Indianapolis v. Edmond, 531 U.S. 32 (2000), curtailed law enforcement authority to use drug-sniffing dogs at roadblocks on the grounds that the DUI checkpoints sanctioned in Sitz were "designed to serve special needs, beyond the normal need for law enforcement," id. at 37 (internal quotations omitted), whereas suspicionless searches using drug-sniffing dogs at roadblocks impermissibly extended into the realm of investigating "ordinary criminal wrongdoing." Id. at 38. Nonetheless, Sitz remains good law insofar as it permits stops of vehicles at DUI checkpoints without any particularized suspicion of impaired driving.

65 Vernonia School Dist. 47J v. Acton, 515 U.S. 646, 664-65 (1995). The majority in Vernonia employed a "special needs" rationale similar to the road safety one utilized in Sitz. 
No. 92 of Pottawatomie County v. Earls extended that reasoning to uphold random drug testing of all students who participate in any extracurricular activities. ${ }^{66}$ Illinois $v$. Wardlow approved an inference of suspicion from flight ${ }^{67}$-an inference that logically extends to any type of evasive behavior. ${ }^{68}$ Whren v. United States upheld pretextual stops, thereby allowing police to conduct stops for minor infractions so they could investigate other, more serious crimes. ${ }^{69}$ And because Minnesota v. Dickerson approved of the so-called "plain feel" exception, ${ }^{70}$ police likely have an incentive to frisk people even when they do not actually fear the presence of a weapon, but rather hope to feel some drugs in the pat down-a seemingly permissible pretext in light of Whren. ${ }^{71}$

In sum, the Terry ruling in 1968 set the initial rules for stop-and-frisk. Since 1980, Court rulings in most of the associated cases have expanded police authority to stop, question, and frisk citizens. This expanded authority undoubtedly increased the risk that officers would employ racial, ethnic, and socio-economic class stereotypes as part of a calculus of suspicion to initiate stop-and-frisk activities. The expansion of stop-and-frisk authority, and the increased risk of racial profiling, is especially problematic when considering the persistent undercurrent of racial injustice throughout nearly two centuries of American policing.

\section{STOP-AND-FRISK AND THE UNDERCURRENT OF RACIAL INJUSTICE ${ }^{72}$}

An undercurrent of racial injustice and discrimination has served as a backdrop in professional policing in the United States for the last 175 years. ${ }^{73}$ The larger race relation problems that have defined American policing provide an

Specifically, concern over the safety of minors under governmental after-school supervision-and not normal law enforcement investigation of criminal wrongdoing-prompted the school district to drug test student-athletes randomly. Id. at 652-53.

66 Bd. of Edu. of Indep. Sch. Dist. No. 92 of Pottawatome Cty. v. Earls, 536 U.S. 822, 825 (2002).

67 Illinois v. Wardlow, 528 U.S. 119, 124 (2000).

68 Hundreds of cases have relied on evasion in a high-crime area to justify Terry stops. See Andrew Guthrie Ferguson \& Damien Bernache, The "High-Crime Area" Question: Requiring Verifiable and Quantifiable Evidence for Fourth Amendment Reasonable Suspicion Analysis, 57 Ам. U. L. REV. 1587, 1590 n.12 (2008).

69 Whren v. United States, 517 U.S. 806, 811-12 (1996).

70 Minnesota v. Dickerson, 508 U.S. 366, 371 (1993).

71 Janet Koven Levit called such pretexts "the Death of Terry v. Ohio." Janet Koven Levit, Pretextual Traffic Stops: United States v. Whren and the Death of Terry v. Ohio, 28 Loy. U. CHI. L.J. 145, 145 (1996); see also Gabriel J. Chin \& Charles J. Vernon, Reasonable but Unconstitutional: Racial Profiling and the Radical Objectivity of Whren v. United States, 83 Geo. WASH. L. Rev. 882 (2015).

72 Portions of Part III are adapted from White \& Fradella, supra note 2, at ch. 6.

73 White \& FRADELla, supra note 2, passim. 
important lens through which to view the rulings in Terry and subsequent cases, as well as the increasing reliance on mass stop-and-frisk programs in New York and elsewhere.

\section{A. Racial Issues in Terry v. Ohio}

In his opinion in Terry v. Ohio, Chief Justice Warren noted that stop-and-frisk activities by police contributed to racial strife:

We would be less than candid if we did not acknowledge that this question thrusts to the fore difficult and troublesome issues regarding a sensitive area of police activity - issues which have never before been squarely presented to this Court. Reflective of the tensions involved are the practical and constitutional arguments pressed with great vigor on both sides of the public debate over the power of the police to "stop and frisk"- as it is sometimes euphemistically termed — suspicious persons. ${ }^{74}$

The opinions in Terry, however, omitted or glossed over several important facts relevant to the racial issues underlying the case. Indeed, nowhere in any of the opinions in Terry does any justice mention that both Terry and Chilton were black men. ${ }^{75}$ Nor does any justice mention that Katz, who was white, was not charged; he was held as a "suspicious person" and released after two days. ${ }^{76}$ According to the transcript of the trial court's suppression hearing in Terry, Officer McFadden testified that when he saw the men standing on the street, "they didn't look right to [him] at the time." ${ }^{, 77}$ Criminologists Delores Jones-Brown and Brian Maule suggested that McFadden's attention may have been drawn to the men on account of their race. ${ }^{78}$ This conclusion is bolstered by a number of ambiguities and inconsistencies in Officer McFadden's account of the case, as law professor Lewis R. Katz explained:

[McFadden] was not acquainted with either man by name or sight, and he had received "[a]bsolutely no information regarding [the] men at all." Officer McFadden did not explain what about the two men "didn't look right" to him. The two men were dressed in topcoats, the standard dress

74 Terry v. Ohio, 392 U.S. 1, 9-10 (1968).

75 John Q. Barrett, Appendix B: State of Ohio v. Richard D. Chilton and State of Ohio v. John W. Terry: The Suppression Hearing and Trial Transcripts, 72 ST. JoHN's L. REV. 1387 (1998).

76 Id. at 1465.

77 Id. at 1456.

78 Delores Jones-Brown \& Brian A. Maule, Racially Biased Policing: A Review of the Judicial and Legislative Literature, in RAce, Ethnicity, And Policing: New And Essential REAdings 140, 145 (Stephen K. Rice \& Michael D. White eds., 2010). 
of the day. They were engaged in no unusual behavior when they initially attracted McFadden's attention. When pressed on what about the two men attracted his interest and whether he would pursue them as he did if he saw them that day across from the courthouse, Officer McFadden replied, "I really don't know."

What happened as McFadden studied Terry and Chilton depends upon which version of Officer McFadden's statement of the facts one reads and in which court opinion the facts appear. McFadden watched the men over a period ten minutes. He watched as one of the two men left the other and walked down the street and looked inside a shop window and continued walking, and then walked back to the other man, again looking in the shop window. The second man then repeated the same behavior. That behavior is the critical conduct which gives rise to the stop in this case. If they did it once or twice each, their behavior was pretty unremarkable. So, how many times they looked in the store window is crucial. In the police report filed the same day as the incident, Officer McFadden wrote that the men did this "about three times each." Between the day of the event when he wrote the police report and his memory was freshest, and the suppression hearing, which was almost one year to the day after the event, Officer McFadden's memory changed. At the suppression hearing three times each became "at least four or five times apiece," which later turned into four to six trips each. Moreover, at trial, when asked how many trips he observed, Officer McFadden replied, "about four trips, three to four trips, maybe four to five trips, maybe a little more, it might be a little less. I don't know, I didn't count the trips." The Ohio Court of Appeals decision in the case picked up on the uncertainty and asserted that the men separated and looked in the window "at least two to five times" each. However, by the time the fact worked its way into Chief Justice Warren's majority opinion in the Supreme Court, the number expands exponentially. He wrote that the men did this "between five or six times apiece-in all roughly a dozen trips." Later in the majority opinion, Chief Justice Warren came up with still another number when he described Terry and Chilton's behavior: "where these men pace alternately along an identical route, pausing to stare in the same store window roughly twenty-four times." The body of law which stems from Terry is dependent upon this single fact.

Officer McFadden was never sure which store was the subject of the suspects' attention. At the suppression hearing he admitted he had no experience in observing the activities of individuals who were "casing" a store for a robbery. In the police report, Officer McFadden indicated that 
they were looking in an airline ticket office; at the suppression hearing, the Detective mentioned an airline office or a jewelry store. ${ }^{79}$

In light of these facts-McFadden's inability to explain why he was initially suspicious of the men, the ever-changing number of trips the men made up and down the street, and the uncertainty of the type of store into which the men were looking - the reasonableness of the initial stop appears to be more open to debate than the Terry decision suggests. The failure of the Court to address the questionable reasonableness of the stop in Terry illustrates how the very foundation of the reasonable suspicion standard in American constitutional law masks racially disparate stop-and-frisk practices with the cloak of race-neutrality. ${ }^{80}$

\section{B. Racial Issues Throughout American Policing}

Police scholars George Kelling and Mark Moore developed a widely cited historical framework that contextualizes 150 years of police history into three eras: political, reform, and community problem-solving. ${ }^{81}$ Though the Kelling and Moore framework is useful for examining police history, it has been criticized for overlooking the role of racism in professional policing. Hubert Williams and Patrick Murphy, for example, argue that the origins of American policing are rooted in slave patrols in the South, and that the advances that have occurred through the "reform" and "community problem-solving" eras excluded minority citizens. ${ }^{82}$ In effect, as policing progressed through the political, professional and community problem-solving eras, the minority community was left behind. Williams and Murphy referred to this as the "minority view" of policing.

Kelling and Moore published their framework in the late 1980s, but the experiences of numerous agencies with stop-and-frisk suggest that Williams and Murphy's "minority view" of policing is still a stark reality. The Philadelphia Police Department (PPD) stopped more than 250,000 citizens in 2009, prompting the American Civil Liberties Union of Pennsylvania (ACLU-PA) to file a federal lawsuit in November 2010..$^{83}$ The lawsuit, Bailey v. City of Philadelphia, alleged that the PPD was engaged in racial profiling. The litigation resulted in a settlement agreement between the plaintiffs and the Philadelphia Police Department that centered on quarterly analysis of stop data by the ACLU-PA, appointment of an

79 Katz, supra note 12, at 430-32 (footnotes omitted).

80 See McAffee, supra note 12, at 612-13; Maclin, supra note 12, at 1278-79.

81 George L. Kelling \& Mark H. Moore, The Evolving Strategy of Policing, 4 PersPectives ON Policing 2 (1988), http://www.innovations.harvard.edu/sites/default/files/114213.pdf.

82 Hubert Williams \& Patrick V. Murphy, The Evolving Strategy of Police: A Minority View, 13 Perspectives on Policing 1 (1990), http://www.ncjrs.gov/pdffiles1/nij/121019.pdf.

83 Complaint at 21, Bailey v. City of Philadelphia, No. 210CV05952, 2010 WL 4662865 (E.D. Pa. Nov. 4, 2010), http://www.aclupa.org/download_file/view_inline/669/198/. 
independent monitor, retraining of officers, and new protocols governing stop-andfrisk practices. ${ }^{84}$ The ACLU-PA subsequently reported to the court and the settlement monitor that although the number of stops had declined by $15 \%,{ }^{85}$ there had been

no significant improvement in the quality of stops and frisks. By our analysis, pedestrian stops are being made without reasonable suspicion in approximately $43-47 \%$ of the cases . . . . Frisks are being conducted without reasonable suspicion in over $45 \%$ of the cases . . . By race, $76 \%$ of the stops were of minorities (African-Americans and Latinos) and $85 \%$ of the frisks were of minorities. The findings as to impermissible stops and frisks are particularly disturbing given the fact that the Police Department had the time and resources following the entry of the Agreement to re-train its officers on stop and frisk practices and to establish supervisory reviews to ensure accountability for practices that failed to meet clear mandates under the Agreement. ${ }^{86}$

The ACLU-PA's most recent report (as of the writing of this article) continues to raise questions about the PPD's use of Terry stops. The 2015 report found that $37 \%$ of stops lacked reasonable suspicion; contraband was only found in $2 \%$ of stops and $5 \%$ of frisks; and blacks comprised approximately $72 \%$ and $79 \%$ of all stops and frisks, respectively, while they made up only $43 \%$ of Philadelphia's population. ${ }^{87}$

In 2013, the American Civil Liberties Union of New Jersey (ACLU-NJ) evaluated six months of stop-and-frisk practices in Newark. According to the ACLU-NJ, the Newark Police Department conducted an average of 2,093 stops per month from July to December 2013. ${ }^{88}$ The authors note that this translates to a rate of 91 stops per 1,000 residents, a stop rate that was eleven times greater than the NYPD stop rate during the same time period. ${ }^{89}$ The ACLU-NJ report also discovered racial disproportionality in stops, as Blacks represented $52 \%$ of the

\footnotetext{
84 Settlement Agreement, Class Certification \& Consent Decree at 3-5, Bailey v. City of Philadelphia, No. 10-5952 (E.D. Pa. June 21, 2011), http://www.aclupa.org/download_file/view_inline/744/198/.

85 Plaintiffs' Third Report to Court and Monitor on Stop and frisk Practices at 4, Bailey v. City of Philadelphia, No. 10-5952 (E.D. Pa. Mar. 19, 2013), http://www.clearinghouse.net/chDocs/public/PN-PA-0013-0003.pdf.

86 Id. at 4-5 (footnote omitted).

87 Plaintiffs' Fifth Report to Court and Monitor on Stop and Frisk Practices at 7-15, Bailey v. City of Philadelphia, No. 10-5952 (E.D. Pa. Feb. 24, 2015), http://www.aclupa.org/download_file/view_inline/2230/198/.

88 Ofer \& Rosmarin, supra note 18 , at 6.

89 Id. at 6-7.
} 
population but $75 \%$ of those who were stopped by Newark police. ${ }^{90}$ An investigation into Terry stops by the Miami Gardens Police Department found that, from 2008-2013, officers had stopped 65,328 individuals, and nearly 1,000 citizens had been stopped 10 or more times. ${ }^{91}$ In 2015, the American Civil Liberties Union of Illinois (ACLU-IL) published a report claiming that the Chicago Police Department had "failed to train, supervise and monitor law enforcement in minority communities for decades, resulting in a failure to ensure that officers' use of stop and frisk is lawful." 92 These stop-and-frisk stories are consistent with Williams and Murphy's "minority view" and demonstrate the perpetuation of the undercurrent of racial injustice in American policing. ${ }^{93}$

Also consider the highly publicized deaths of Eric Garner, Michael Brown, and Freddie Gray - all of which involved Terry stops. On July 17, 2014, NYPD officers approached Eric Garner on a street corner in Staten Island because they suspected that he was selling unlicensed cigarettes. ${ }^{94}$ The incident was captured on a bystander's cell phone. After brief questioning, officers attempted to take Garner, a 400-pound man, into custody. During the struggle, Officer Daniel Pantaleo applied a chokehold and Garner can be heard stating nearly a dozen times that he cannot breathe. Garner lost consciousness after the struggle; he was pronounced dead an hour later. Five months later, a grand jury refused to indict Officer Pantaleo, sparking waves of protests. ${ }^{95}$

On August 9, 2014, Ferguson police officer Darren Wilson observed Michael Brown and Dorian Johnson walking in the middle of the street. There is no video of the incident and the facts are disputed, but what is clear is that the initial stop of Brown and Johnson led to a struggle between Wilson, who was still seated in his patrol car, and Brown, who was next to the car. ${ }^{96}$ Physical evidence supports Officer Wilson's assertion that there was a struggle over Wilson's gun and that one

$90 \quad$ Id. at 9.

91 Alice Brennan \& Dan Lieberman, Florida City's "Stop and Frisk" Nabs Thousands of Kids, Finds 5-year-olds “suspicious,” Fusion (May 9, 2014), http://fusion.net/story/5568/floridacitys-stop-frisk-nabs-thousands-of-kids-finds-5-year-olds-suspicious/.

92 Am. Civil Liberties Union OF ILL., STOP AND FRISK IN CHICAGO 2 (2015), http://www.acluil.org/wp-content/uploads/2015/03/ACLU_StopandFrisk_6.pdf.

93 See Williams \& Murphy, supra note 82, passim.

94 See Jericka Duncan, Eric Garner Case: Video of Chokehold's Aftermath Raises New Questions, CBS NEws (Dec. 6, 2014), http://www.cbsnews.com/news/second-tape-of-nypdchokehold-raises-new-questions-in-eric-garner-case/.

95 Id.; see also J. David Goodman \& Al Baker, Wave of Protests After Grand Jury Doesn't Indict Officer in Eric Garner Chokehold Case, N.Y. Times (Dec. 3, 2014), http://www.nytimes.com/2014/12/04/nyregion/grand-jury-said-to-bring-no-charges-in-staten-islandchokehold-death-of-eric-garner.html.

96 Matt Pearce, Back Story: What Happened in Michael Brown Shooting in Ferguson, Mo.?, L.A. Times (Nov. 24, 2014), http://www.latimes.com/nation/la-na-back-story-ferguson-shootingstory.html. 
shot was fired while he was still in his car. ${ }^{97}$ Wilson got out of the patrol car and fired several more shots that killed Michael Brown. Officer Wilson claimed that Brown had turned and was charging at him. Other testimony indicated that Brown had his hands up and was posing no threat to Wilson. ${ }^{98}$ Protests and civil disorder began shortly after Brown's death and continued for several days. On August 16, 2014, Missouri Governor Jay Nixon declared a state of emergency in Ferguson. On November 24, 2014, a grand jury declined to indict Officer Wilson for Michael Brown's death. ${ }^{99}$

On April 12, 2015, Baltimore police officers attempted to stop and question Freddie Gray. Gray fled from the officers, but he was quickly taken into custody and arrested for possessing an illegal switchblade. During his transport in a police van, Gray slipped into a coma and died several days later on April 19th. ${ }^{100}$ Autopsy findings indicate that Gray died from injuries to his spinal cord. ${ }^{101}$ Though there are questions about whether force was used during the arrest, Baltimore Police Commissioner Anthony Batts acknowledged that Freddie Gray was not properly secured during the van transport. Protests and civil disorder erupted after Gray's death. On May 1, 2015, six officers were charged with Freddie Gray's death by the State Attorney's Office, and on May 21, 2015, a grand jury indicted the six officers. ${ }^{102}$ A mistrial was declared in the first trial of one of the officers after the jury failed to reach a unanimous verdict. ${ }^{103}$

The numerous allegations of racial profiling that have emerged in the wake of stop-and-frisk programs, and the deaths of Eric Garner, Michael Brown, and Freddie Gray demonstrate the persistent undercurrent of racial injustice in American policing - or what Williams and Murphy termed the "minority view" of

97 U.S. Dep't of Justice, Department of Justice Report Regarding the Criminal Investigation Into the Shooting Death of Michael Brown by Ferguson, Missouri Police OfFICER DARREN WiLSON 16-26 (Mar. 4, 2015), https://www.justice.gov/sites/default/files/opa/pressreleases/attachments/2015/03/04/doj_report_on_shooting_of_michael_brown_1.pdf.

98 Id. at 27-35.

99 Monica Davey \& Julie Bosman, Protests Flare After Ferguson Police Officer Is Not Indicted, N.Y. TiMES (Nov. 24, 2014), http://www.nytimes.com/2014/11/25/us/ferguson-darrenwilson-shooting-michael-brown-grand-jury.html?_r=0.

100 David A. Graham, The Mysterious Death of Freddie Gray, AtLantic (Apr. 22, 2015), http://www.theatlantic.com/politics/archive/2015/04/the-mysterious-death-of-freddie-gray/391119/.

101 Justin Fenton, Autopsy of Freddie Gray Shows 'High-energy' Impact, BALT. Sun (June 24, 2015), http://www.baltimoresun.com/news/maryland/freddie-gray/bs-md-ci-freddie-gray-autopsy20150623-story.html.

102 Richard Pérez-Peña, Six Baltimore Officers Indicted in Death of Freddie Gray, N.Y. Times (May 21, 2015), http://www.nytimes.com/2015/05/22/us/six-baltimore-officers-indicted-in-death-offreddie-gray.html.

103 Justin Fenton \& Kevin Rector, Mistrial Declared in Trial of Officer William Porter in Death of Freddie Gray, BALT. SuN (Dec. 16, 2015), http://www.baltimoresun.com/news/maryland/freddie-gray/bs-md-porter-trial-jury-wednesday20151216-story.html. 
policing. ${ }^{104}$ Although many U.S. cities continue to struggle with racial and ethnic tensions in police-citizen relationships, the unique ways in which stop-and-frisk was implemented in New York contributed to that particular city having one of the most vexing and persistent problems with policing communities of color.

\section{STOP-AND-FRISK AND THE NYPD}

The NYPD story demonstrates how use of stop-and-frisk as a widespread crime-control strategy can go terribly wrong, leading to the violation of the constitutional rights of thousands of mostly minority New York City residents for a period of nearly twenty years. The story represents a collision between a constitutionally permissible tactic used in an unconstitutional manner, the persistent undercurrent of racial injustice in policing, and an effort to use federal civil litigation as a mechanism to force police reform. The next section describes how this collision developed.

\section{A. Crime, Disorder, and Broken Windows}

New York City, like many cities across the United States, experienced a major spike in violence, crime, and disorder in the 1980s. ${ }^{105}$ Much of the violence in New York was driven by the emergence of crack cocaine and competition for the drug market. ${ }^{106}$ Homicides climbed steadily from 1,392 in 1985 to 2,262 in 1990. ${ }^{107}$ At the same time, the city and subway system were struggling with rampant social and physical disorder. ${ }^{108}$ Marijuana, heroin, cocaine, and crack cocaine were regularly and openly being sold on street corners, blocks, and city parks. ${ }^{109}$ Kelling and Coles estimated that "[a]pproximately 1,200 to 2,000 persons a night" were sleeping in the subway system. ${ }^{110}$

104 See Williams \& Murphy, supra note 82, passim.

105 For a full discussion on the NYPD prior to 1994, see JAMES LARDNER \& THOMAS RePPETTO, NYPD: A CitY AND ITS POLICE (2000).

106 See generally Roland G. Fryer, Jr., Paul S. Heaton, Steven D. Levitt \& Kevin M. Murphy, Measuring Crack Cocaine and Its Impact, 51 ECON. INQUIRY 1651 (2013).

107 Michael D. White, The New York City Police Department, Its Crime Control Strategies and Organizational Changes, 1970-2009, 31 JusT. Q. 74, 79 (2014).

108 George L. Kelling \& Catherine M. Coles, Fixing Broken Windows: Restoring Order ANd Reducing Crime in Our Communities 117-18 (1996).

109 Bruce D. Johnson, Andrew Golub \& James E. McCabe, The International Implications of Quality-of-Life Policing as Practiced in New York City, 11 Police Prac. \& Res. 17, 18 (2010).

110 Kelling \& Coles, supra note 108, at 117-18. 
The New York Transit Authority appointed William Bratton as chief of the transit police to address crime and disorder in the subway system. ${ }^{111}$ Chief Bratton partnered with criminologist George Kelling to develop an enforcement strategy (based on Wilson and Kelling's "broken windows" theory ${ }^{112}$ ) that targeted lowlevel offenses (e.g., turnstile jumping), as well as social and physical disorder through frequent arrests and removals from the subway system. ${ }^{113}$ Broken windows theory posits that minor forms of social and physical disorder cause a breakdown in informal social control as citizen investment in an area diminishes. ${ }^{114}$ As citizens withdraw from the area, the level of disorder increases and the risk for more serious types of crime to emerge becomes greater. ${ }^{115}$ The theory suggests that police focus enforcement efforts on disorder and quality-oflife offenses as a mechanism for reengaging law-abiding citizens' commitment to the area. ${ }^{116}$ Under Chief Bratton, the transit police adopted a broken windowsbased strategy in the subway system. Over the next two years, the level of disorder dropped dramatically, and felony offenses declined by $30 \%{ }^{117}$

In 1993, New York City Mayor Rudolph Giuliani appointed William Bratton as the Commissioner of the NYPD, and Bratton immediately began implementation of a broken-windows based strategy throughout New York. ${ }^{118}$ Two policy initiatives defined the NYPD crime-control strategy. First, Reclaiming the Public Spaces of New York outlined the broken windows theory and articulated an order maintenance strategy that targeted disorder and quality-of-life offenses through systematic and aggressive enforcement strategies (e.g., replicating the subway strategy). ${ }^{119}$ Second, Getting Guns off the Streets of New York ${ }^{120}$ outlined

111 The Life and Times of Incoming NYPD Commissioner William Bratton, N.Y. DAILY NEWS, (Dec. 5, 2013), http://www.nydailynews.com/news/politics/timeline-new-nypd-commissionerbratton-article-1.1538689.

112 See George L. Kelling \& James Q. Wilson, Broken Windows: The Police and Neighborhood Safety, AtLantic Monthly, Mar. 1982, at 29.

113 See Ana Joanes, Does the New York City Police Department Deserve Credit for the Decline in New York City's Homicide Rates? A Cross-City Comparison of Policing Strategies and Homicide Rates, 33 Colum. J.L. \& Soc. Probs. 265 (2000) (citing Jackson Toby, Reducing Crime: New York's Example, WAsH. Post, July 23, 1996, at A17).

114 Kelling \& Wilson, supra note 112.

115 Id. at 37.

116 Id.

117 Joanes, supra note 113, at 265.

118 Alison Mitchell, Giuliani Appoints Bostonian to Run New York's Police, N.Y. Times (Dec. 3, 1993), http://www.nytimes.com/1993/12/03/nyregion/giuliani-appoints-bostonian-to-run-newyork-s-police.html.

119 N.Y. City Police Dep't, Police Strategy No. 5: Reclaiming the Public Spaces of New YORK (1994).

120 N.Y. City Police Dep't, Police Strategy No. 1: Getting Guns Off the Streets of New YORK (1994). 
the NYPD's strategy to reduce gun violence through the seizure of illegal firearms and through the intensive investigation of gun-related incidents. ${ }^{121}$

Stop-and-frisk emerged as the primary tactic to meet the objectives of both policy initiatives. ${ }^{122}$ Over the next several years, critics argued that police overenforced quality-of-life infractions through a zero-tolerance approach because officers could easily justify the stops under the reasonable suspicion standard. ${ }^{123}$ As Waldeck states, there is not "any doubt that the police use quality-of-life offenses as excuses to fish for drugs, guns, or evidence of a more serious crime." 124 The effects of the stop-and-frisk program were immediate. From 1993 to 1996, arrests rose by $23 \%$, including a $40 \%$ increase in misdemeanor arrests and a $97 \%$ increase in drug arrests. ${ }^{125}$ The NYPD made approximately 40,000 gun-related arrests over a three-year period, resulting in the removal of more than 50,000 guns from the streets. ${ }^{126}$ Stop-and-frisk also produced a large increase in arrests for marijuana possession. In 2006, Geller and Fagan reported that there were 32,000 arrests for marijuana possession, marking a $500 \%$ increase from the previous decade. $^{127}$

The NYPD's use of stop-and-frisk increased steadily in the late 1990s into the twenty-first century. In 2003, for example, NYPD officers conducted more than 160,000 stop-and-frisks of citizens. ${ }^{128}$ In 2003, the NYPD implemented Operation Impact, a hot spots strategy where police commanders identified twenty four highcrime "Impact Zones" that would be targeted with "saturation foot patrol in combination with resources from a variety of departmental divisions." 129 Stopand-frisk activity increased dramatically over the next several years, peaking at

121 See Dennis C. Smith \& William J. Bratton, Performance Management in New York City: Compstat and the Revolution in Police Management, in QuiCKer, Better, CheAPer: MANaging Performance in American Government 453 (Dall W. Forsythe ed., 2001).

122 White, supra note 107 , at 84.

123 Jeffrey Fagan \& Garth Davies, Street Stops and Broken Windows: Terry, Race, and Disorder in New York City, 28 Fordham URB. L.J. 457, 476 (2000).

124 Sarah E. Waldeck, Cops, Community Policing, and the Social Norms Approach to Crime Control: Should One Make Us More Comfortable with the Others?, 34 GA. L. REV. 1253, 1282 (1999).

125 White, supra note 107, at 82 (citing Judith A. Greene, Zero Tolerance. A Case Study of Police Policies and Practices in New York City, 45 CRIME \& DeLINQUENCY 171 (1999)).

126 See Garen Wintemute, Guns and Gun Violence, in THE CRIME Drop IN AMERICA 45 (Alfred Blumstein \& Joel Wallman eds., rev. ed. 2006).

127 Amanda Geller \& Jeffrey Fagan, Pot as Pretext: Marijuana, Race, and the New Disorder in New York City Street Policing, 7 J. EMPIRICAL LEGAL STUD. 591, 592 (2010).

128 NYPD STOP-AND-FRISK DATABASE, supra note 20.

129 David Weisburd, Cody W. Telep \& Brian A. Lawton, Could Innovations in Policing Have Contributed to the New York City Crime Drop Even in a Period of Declining Police Strength?: The Case of Stop, Question and Frisk as a Hot Spots Policing Strategy, 31 JusT. Q. 129, 136-37 (2014). 
more than 685,000 in 2011. ${ }^{130}$ As the frequency of stops increased, critics attacked the strategy's low rates of return. Jones-Brown and colleagues found that of the 540,320 stops in 2008, just 6\% (32,206 stops) resulted in an arrest and an additional $6.4 \%$ (34,802 stops) resulted in a summons; thus, the percentage of "innocent stops"- those not resulting in summons or arrest-accounted for roughly $87.6 \% .{ }^{131}$ Similarly, the percentage of stops resulting in the recovery of a gun dropped by $60 \%$ from $0.39 \%$ (627 guns recovered out of a total of 160,851 stops) in 2003 to $0.15 \%$ in 2008 (824 guns recovered out of a total of 540,320 stops). ${ }^{132}$ Furthermore, the percentage of citizen complaints involving stops increased from $24.6 \%$ in 2004 to $32.7 \%$ in $2008 .{ }^{133}$

As the use of stop-and-frisk expanded dramatically, the NYPD drifted away from the central tenets of broken windows theory, and the program devolved into a strictly zero-tolerance approach against social disorder such as public drunkenness, vandalism, loitering, panhandling, prostitution, and the like. ${ }^{134}$ In other words, rather than focusing on the "amelioration of physical disorder" in partnership with the community, the NYPD focused on "interdiction of social disorder."135 These efforts led the NYPD to implement a set of practices that encouraged the aggressive pursuit of individuals through stop-and-frisks, rather than mutually beneficial interactions with law-abiding citizens. ${ }^{136}$ This zero-tolerance mentality compounded the police department's disconnect from the community in a number of important ways. First, the NYPD focused less on preventing disorder and alternatives to arrest, and more on aggressively removing weapons and wanted criminals from the community. ${ }^{137}$ Second, the NYPD de-emphasized informal interactions between police and the community in the manner advocated by both community policing principles and broken windows theory. ${ }^{138}$ The lack of policecommunity engagement was driven in large part by the management style that Bratton embraced from the private sector. ${ }^{139}$ This management style stressed

\footnotetext{
130 NYPD STOP-AND-FRISK DATABASE, supra note 20.

131 Delores Jones-Brown, Jaspreet Gill \& Jennifer Trone, Stop, Question \& Frisk Policing Practices in NeW York City: A Primer 10-11 (2010), http://static.prisonpolicy.org/scans/PRIMER_electronic_version.pdf.

132 Id. at 10-13 fig.8B.

133 Id. at 14 fig.9.

134 Waldeck, supra note 124, at 1273-74.

135 Fagan \& Davies, supra note 123, at 468.

136 Waldeck, supra note 124, at 1274.

137 Fagan \& Davies, supra note 123, at 471-72.

138 Michael D. White, Henry F. Fradella \& James R. Coldren, Jr., Why Police (and Communities) Need 'Broken Windows,' Crime Report (Aug. 11, 2015), http://thecrimereport.org/2015/08/11/2015-08-why-police-and-communities-need-broken-windows/.

139 See generally Michael HAMMER \& JAMEs CHAMPy, REENGINEERING THE CORPORATION: A MANiFESTO FOR BUSINESS REVOLUTION (1993).
} 
innovative approaches on management accountability, prioritization, and datadriven decision-making. ${ }^{40}$ One of the primary structural modifications to emerge from this management system was Compstat, a system "defined by timely and accurate information, rapid deployment of resources, effective tactics, follow-up, and assessment." ${ }^{\text {"141 }}$ Essentially, instead of identifying community needs through engagement with residents, the NYPD determined community needs through its own data-driven accountability system (i.e., Compstat).

\section{B. Crime Control Benefits}

During the same time that the NYPD implemented its order-maintenance strategy to target disorder, illegal gun carrying, and crime (with stop-and-frisk as a central feature), the city witnessed a large, prolonged drop in crime. From the mid-1990s to the mid-2000s, street crime in New York City declined approximately $75 \%$ - a decrease roughly twice the national average. ${ }^{142}$ In 2007, there were 496 homicides in New York, down from more than 2,200 in 1990.

Proponents of stop-and-frisk point to New York City's crime decline over the last two decades as evidence that the tactic is effective. For example, former NYPD Commissioner Raymond Kelly touted stop-and-frisk at a news conference by saying:

Police stops are just one component of multiple efforts by the Department that have saved lives and driven the murder rate to record lows. In the first 11 years of Mayor Bloomberg's tenure there were 7,363 fewer murders in New York City compared to the 11 years prior to the Mayor taking office. ${ }^{143}$

Former New York City Mayor Michael Bloomberg similarly praised the effectiveness of stop-and-frisk in combatting crime, stating: "New York is the safest big city in the nation, and our crime reductions have been steeper than any

140 Id.; see also James J. Willis, Stephen D. Mastrofski \& David Weisburd, Making Sense of COMPSTAT: A Theory-Based Analysis of Organizational Change in Three Police Departments, 41 LAW \& SOC'Y REV. 147, 151 (2007).

141 White, supra note 107 , at 81.

142 See Weisburd et al., supra note 129, at 2; see also FrankLin E. Zimring, The City That

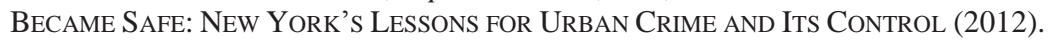

143 New York Police Commissioner Ray Kelly Calls Stop-and-Frisk Decision 'Disturbing and

Offensive' (Transcript), N.Y. DAILY NEWS (Aug. 12, 2013), http://www.nydailynews.com/news/politics/new-york-police-commissioner-ray-kelly-commentsstop-and-frisk-decision-article-1.1424689. 
other big city's. For instance, if New York City had the murder rate of Washington, D.C., 761 more New Yorkers would have been killed last year."144

Whether stop-and-frisk caused or contributed to the crime decline in New York City is a hotly contested proposition. ${ }^{145}$ Several studies have suggested a causal connection. Corman and Mocan reported that misdemeanor arrests were associated with declines in robbery, motor vehicle theft, and grand larceny, but not homicide, assault, burglary, and rape. ${ }^{146}$ Similarly, Kelling and Sousa found that misdemeanor arrest levels were significantly associated with reductions in violent crime, while controlling for several relevant community factors. ${ }^{147}$ Smith and Purtell found that Operation Impact had a significant effect on crimes-againstpersons in Impact Zones. ${ }^{148}$ Smith and Purtell also examined the effects of stopand-frisk on crime in New York, and they found that there was a significant inverse relationship between stop rates and robbery, burglary, motor vehicle theft, and homicides rates. ${ }^{149}$ Zimring argued that New York's crime decline from 1990 through 2009 was largely attributable to the NYPD's policing practices. ${ }^{150}$

Conversely, there are a number of studies indicating that the relationship between stop-and-frisk and the crime decline in New York City is modest at best. $^{151}$ For instance, Rosenfeld and Fornango found that police stops did not

144 Michael R. Bloomberg, Opinion, Michael Bloomberg: 'Stop and Frisk' Keeps New York Safe, WAsH. Post (Aug. 18, 2013), https://www.washingtonpost.com/opinions/michael-bloombergstop-and-frisk-keeps-new-york-safe/2013/08/18/8d4cd8c4-06cf-11e3-9259-e2aafe5a5f84_story.html.

145 For full treatment of this question, see 31 JusT. Q. 1 (2014) (special issue on the New York City crime decline).

146 Hope Corman \& Naci Mocan, Carrots, Sticks, and Broken Windows, 48 J.L. \& Econ. 235, 255 tbl.3 (2005); see also Robert C. Davis \& Pedro Mateu-Gelabert, Respectful and Effective Policing: Two ExAmples IN THE SOUTH BronX http://archive.vera.org/sites/default/files/resources/downloads/respectful_policing.pdf.

147 George L. Kelling \& William H. Sousa, Jr., Manhattan Inst., Do Police Matter? An ANAlysis of the Impact of NeW York City's Police Reforms Executive Summary (2001), http://www.manhattan-institute.org/pdf/cr_22.pdf.

148 Dennis C. Smith \& Robert Purtell, An EMpirical Assessment of NYPD’s “Operation IMPACT": A TARgETED ZONE CRIME Reduction STRATEgy 9 (2007), http://wagner.nyu.edu/files/faculty/publications/impactzoning.doc.

149 See Report of Dennis C. Smith, Ph.D. at 19 \& 63, n.32, Floyd v. City of New York, 813 F.Supp.2d 457 (S.D.N.Y. Nov. 15, 2010) (No. 08 Civ. 01034), 2010 WL 9532297 (citing Dennis Charles Smith \& Robert Purtell, Does Stop-and-Frisk Stop Crime? (paper presented at the Annual Research Conference of the Association of Public Policy and Management in Nov. 2008)); see also Dennis C. Smith, Opinion, Stop and Frisk Has Lowered Crime in Other Cities, N.Y. Times (July 19, 2012), http://www.nytimes.com/roomfordebate/2012/07/17/does-stop-and-frisk-reduce-crime/stopand-frisk-has-lowered-crime-in-other-cities.

150 ZIMRING, supra note 142, passim.

151 Magdalena Cerdá, Melissa Tracy, Steven F. Messner, David Vlahov, Kenneth J. Tardiff \& Sandro Galea, Misdemeanor Policing, Physical Disorder, and Gun-Related Homicide: A Spatial Analytic Test of "Broken-Windows" Theory, 20 Epidemiology 533, 537-38 (2009); Magdalena Cerdá, Steven F. Messner, Melissa Tracy, David Vlahov, Emily Goldmann, Kenneth J. Tardiff \& 
decrease robbery and burglary rates. ${ }^{152}$ In a re-analysis of Kelling and Sousa's data, Harcourt and Ludwig found no significant relationships between policing minor disorder offenses and New York City's crime decline. ${ }^{153}$ MacDonald and colleagues conducted a comprehensive examination of the crime effects of Operation Impact (with a specific focus on stop-and-frisk). They concluded:

Impact zones were significantly associated with reductions in total reported crimes, assaults, burglaries, drug violations, misdemeanor crimes, felony property crimes, robberies, and felony violent crimes. Impact zones were significantly associated with increases in total reported arrests, arrests for burglary, arrests for weapons, arrests for misdemeanor crimes, and arrests for property felony crimes. Impact zones were also significantly associated with increases in investigative stops for suspected crimes, but only the increase in stops made based on probable cause indicators of criminal behaviors were associated with crime reductions. The largest increase in investigative stops in impact zones was based on indicators of suspicious behavior that had no measurable effect on crime. The findings suggest that saturating high crime blocks with police helped reduce crime in New York City, but that the bulk of the investigative stops did not play an important role in the crime reductions. The findings indicate that crime reduction can be achieved with more focused investigative stops. ${ }^{154}$

\section{The Social Costs}

Regardless of the impact on crime, there is considerable evidence demonstrating that the NYPD's stop-and-frisk program exacted significant social costs that were disproportionately experienced by ethnic minorities. By the end of the 1990s, stop-and-frisk had become a point of contention among ethnic minorities. A Vera Institute of Justice study examined the experiences of more than 500 people who had been stopped by the NYPD:

Sandro Galea, Investigating the Effect of Social Changes on Age-Specific Gun-Related Homicide Rates in New York City During the 1990s, 100 Am. J. Pub. Health 1107, 1111-12 (2010); Richard Rosenfeld, Robert Fornango \& Andres F. Rengifo, The Impact of Order-Maintenance Policing on New York City Homicide and Robbery Rates: 1988-2001, 45 CRIMINOLOGY 355, 375-77 (2007).

152 Richard Rosenfeld \& Robert Fornango, The Impact of Police Stops on Precinct Robbery and Burglary Rates in New York City, 2003-2010, 31 JusT. Q. 96, 116 (2014).

153 Bernard E. Harcourt \& Jens Ludwig, Broken Windows: New Evidence From New York City and a Five-City Social Experiment, 73 U. CHI. L. REV. 271, 276-77 (2006).

154 John MacDonald, Jeffrey Fagan \& Amanda Geller, The Effects of Local Police Surges on Crime and Arrests in New York City, 11 PLoS ONE e0157223, at 1 (Colum. Pub. L. Res. Paper No. 14-468 (June 16, 2016), http://papers.ssrn.com/sol3/papers.cfm?abstract_id=2614058). 
1) $44 \%$ of young people surveyed indicated they had been stopped repeatedly -9 times or more.

2) Less than a third-29\% — reported ever being informed of the reason for a stop.

3) $71 \%$ of young people surveyed reported being frisked at least once, and $64 \%$ said they had been searched.

4) $45 \%$ reported encountering an officer who threatened them, and $46 \%$ said they had experienced physical force at the hands of an officer.

5) One out of four said they were involved in a stop in which the officer displayed his or her weapon.

6) $61 \%$ stated that the way police acted towards them was influenced by their age.

7) $51 \%$ indicated that they were treated worse than others because of their race and/or ethnicity. ${ }^{155}$

A study by Fagan and colleagues on stop-and-frisk in New York City identified three noteworthy findings:

First, stops within neighborhoods take place at rates in excess of what would be predicted from the separate and combined effects of population demography, physical and social conditions, and the crime rate. This excess seems to be concentrated in predominately Black neighborhoods. Second, the excess stops in these neighborhoods persist over time, even as the Black population declines, crime rates remain low and effectively unchanged, the City's overall social and economic health improves, and housing and other investments increase across the City's neighborhoods, including its poorest and most segregated neighborhoods. Third, there appears to be a declining return in crime detection from marginal increases in enforcement, and this efficiency gap seems to grow over time. ${ }^{156}$

The racial focus of the NYPD's stop-and-frisk program was acknowledged (and minimized) by city and police department leaders. ${ }^{157}$ Former Mayor Michael

\footnotetext{
155 Jennifer Fratello, Andrés F. Rengifo, Jennifer Trone \& Brenda VelazQuez, Coming of Age with Stop and Frisk: Experiences, Perceptions, and Public Safety Implications, iii, 34 fig.14 (2013), http://archive.vera.org/sites/default/files/resources/downloads/stop-and-frisk_technicalreport.pdf.

156 Jeffrey A. Fagan, Amanda Geller, Garth Davies \& Valerie West, Street Stops and Broken Windows Revisited: The Demography and Logic of Proactive Policing in a Safe and Changing City, in Race, Ethnicity, and Policing: New and Essential Readings 309, 337 (Stephen K. Rice \& Michael D. White eds., 2010).

157 See, e.g., Ray Kelly, Commentary, The NYPD: Guilty of Saving 7,383 Lives, WALL ST. J. (July 22, 2013), http://www.wsj.com/articles/SB10001424127887324448104578616333588719320.
} 
Bloomberg stated publicly that, according to the department's statistics on violent crime suspects, "we disproportionately stop whites too much and minorities too little." 158 In 2013, an officer in the 40th precinct recorded his commanding officer directing him to stop "the right people, at the right time, at the right location," described as "male blacks, 14 to 20, 21."159 The Center for Constitutional Rights (CCR) interviewed 54 people who had been subjected to stop-and-frisk in order to paint a clearer picture of the "human impact" of the stop-and-frisk program. The CCR concluded:

These interviews provide evidence of how deeply this practice impacts individuals and they document widespread civil and human rights abuses .... The effects of these abuses can be devastating and often leave behind lasting emotional, psychological, social, and economic harm. . . . Residents of some New York City neighborhoods describe a police presence so pervasive and hostile that they feel like they are living in a state of siege. ${ }^{160}$

The overt racially charged statements by city and police leaders, along with clear racial disproportionality in the administration of the stop-and-frisk program, illustrates the persistent undercurrent of racial injustice in New York City policing, and provides an important backdrop for the federal litigation accusing the NYPD of racially-discriminatory policing.

\section{FEDERAL Civil Litigation AS AN INSTRUMENT OF POLICE REFORM}

Given the decentralized nature of law enforcement in the United States, the federal courts are often called upon to address allegations of widespread unconstitutional police practices, such as discriminatory stop-and-frisk practices. ${ }^{161}$ There are several avenues through which federal court relief from unconstitutional

158 Jennifer Fermino, Mayor Bloomberg on Stop-And-Frisk: It Can Be Argued 'We Disproportionately Stop Whites Too Much. And Minorities Too Little,' N.Y. DAILY News (June 28, 2013), http://www.nydailynews.com/new-york/mayor-bloomberg-stop-and-frisk-disproportionatelystop-whites-minorities-article-1.1385410.

159 Graham Rayman, New NYPD Tapes Introduced in Stop and Frisk Trial, VILLAGE VoiCE (Mar. 22, 2013), http://www.villagevoice.com/news/new-nypd-tapes-introduced-in-stop-and-frisktrial-6721026.

160 Ctr. for Constitutional Rights, Stop And Frisk: The Human Impact 1 (2012), http://ccrjustice.org/sites/default/files/attach/2015/08/the-human-impact-report.pdf.

161 Police Exec. Research Forum, Civil Rights Investigations of Local Police: Lessons LEARNED 1 (2013), http://www.policeforum.org/assets/docs/Critical_Issues_Series/civil\%20rights\%20investigations\%20 of\%20local\%20police\%20-\%20lessons\%20learned\%202013.pdf; Stephen Rushin, Federal Enforcement of Police Reform, 82 FordHAm L. REV. 3189 (2014). 
police practices can be pursued, the two most frequently used of which are civil lawsuits filed pursuant to either 42 U.S.C. § 1983 or 42 U.S.C. § 14141.

\section{A. Section 1983}

Section 1983 of the Civil Rights Act of 1871 provides civil and criminal remedies for individuals whose constitutional rights are violated by persons acting under state authority. ${ }^{162}$ Enacted largely in response to growing domestic terrorism by the Ku Klux Klan, the Act provides:

Every person who, under color of any statute, ordinance, regulation, custom, or usage, of any State or Territory or the District of Columbia, subjects, or causes to be subjected, any citizen of the United States or other person within the jurisdiction thereof to the deprivation of any rights, privileges, or immunities secured by the Constitution and laws, shall be liable to the party injured in an action at law, suit in equity, or other proper proceeding for redress[.. $]^{163}$

Section 1983, introduced by Rep. Samuel Shellabarger (R., Ohio), "was the subject of only limited debate and was swiftly passed without amendment." 164 Its primary purpose was to provide a mechanism for private persons to enforce the rights secured by the Fourteenth Amendment. ${ }^{165}$ Although it has been amended a few times since its passage, the language of the Act today remains "essentially unchanged" from the original. ${ }^{166}$

Section 1983 was hardly used from the time of its enactment until the early 1960s. ${ }^{167}$ In 1961, the U.S. Supreme Court decided Monroe v. Pape. ${ }^{168}$ That case upheld the authority of the plaintiff to use $\S 1983$ as a jurisdictional basis for suing police officers who had allegedly conducted an illegal search of his home in

162 An Act to Enforce the Provisions of the Fourteenth Amendment to the Constitution of the United States, and for Other Purposes, ch. 22, § 1, 17 Stat. 13 (1871) (codified as amended at 42 U.S.C. § 1983 (2000)).

163 Id.

164 Ken Gormley, Private Conspiracies and the Constitution: A Modern Vision of 42 U.S.C. Section 1985(3), 64 TeX. L. REv. 527, 537 (1985); Monell v. Dep't of Soc. Serv. of N.Y., 436 U.S. 658, 665 (1978) (citing Cong. GloBe, 42d Cong., 1st Sess., 522 (1871)).

165 See Monroe v. Pape, 365 U.S. 167, 167 (1961), overruled on other grounds by Monell v. Dep't of Soc. Serv. of N.Y., 436 U.S. 658 (1978) (holding municipalities may be sued under Section 1983); Memphis Cmty. Sch. Dist. v. Stachura, 477 U.S. 299, 305 (1986).

166 Jim Thomas, Prisoner Litigation: The Paradox OF the Jailhouse LAWYer 37 (1988).

167 Robert C. Harrall, Prisoners' Section 1983 Cases: A Study of Palmigiano v. Garrahy (unpublished Ph.D. dissertation, University of Connecticut).

168365 U.S. 167. 
violation of the Fourth Amendment. ${ }^{169}$ Notably, the Court refused to allow the lawsuit to proceed against the City of Chicago as the employer of the officers, reasoning that Congress had not intended the word "person" in $\S 1983$ to apply to municipalities. ${ }^{170}$ Of particular relevance to this article, however, the Court reversed itself on this key issue in the 1978 case of Monell v. Department of Social Services of the City of New York: ${ }^{171}$

Our analysis of the legislative history of the Civil Rights Act of 1871 compels the conclusion that Congress did intend municipalities and other local government units to be included among those persons to whom $\S 1983$ applies. Local governing bodies, therefore, can be sued directly under $\S 1983$ for monetary, declaratory, or injunctive relief where, as here, the action that is alleged to be unconstitutional implements or executes a policy statement, ordinance, regulation, or decision officially adopted and promulgated by that body's officers. Moreover, although the touchstone of the $\S 1983$ action against a government body is an allegation that official policy is responsible for a deprivation of rights protected by the Constitution, local governments, like every other $\S 1983$ "person," by the very terms of the statute, may be sued for constitutional deprivations visited pursuant to governmental "custom" even though such a custom has not received formal approval through the body's official decisionmaking channels. ${ }^{172}$

Importantly, municipal practices and customs are so broadly defined in Monell that the terms include whatever the agency does routinely, whether stated in official policy or not, such that the practice amounts to a custom or usage that is tantamount to formal law or policy. ${ }^{173}$

If a number of people have been aggrieved by state actors whose conduct falls within a municipal policy, practice, or custom, those plaintiffs' $\S 1983$ lawsuits may be certified as a class action under Federal Rule of Civil Procedure 23(b)(2). ${ }^{174}$ Such class action lawsuits play a critical role in the enforcement of civil rights. If the plaintiffs are able to establish the requirements to be certified as

169 Id. at 191-92.

170 Id. at $187-92$.

171436 U.S. 658.

172 Id. at 690-91.

173 See, e.g., Martin A. SchwartZ, SECTION 1983 Litigation 97 (3d ed. 2014); see also City of St. Louis v. Praprotnik, 485 U.S. 112, 127 (1988) (quoting Adickes v. S.H. Kress \& Co., 398 U.S. 144, 167-68 (1970)).

174 See, e.g., William A. Margeson, Bringing the Gavel Down on Stops and Frisks: The Equitable Regulation of Police Power, 51 Am. CrIm. L. Rev. 739, 756 (2014). 
a class, as they were in Floyd, they can present evidence to the court and seek federal injunctive relief against a law enforcement agency. ${ }^{175}$

Perhaps because § 1983 claims against municipalities can seek both injunctive relief and monetary remedies, the decision in Monell led to a dramatic increase in civil litigation against police because it "opened the 'deep pockets' of government treasuries to civil rights plaintiffs." ${ }^{176}$ For example, from 1986-1990, the City of Los Angeles paid more than \$20 million in civil litigation against police officers. ${ }^{177}$ In 2001, the State of New Jersey paid $\$ 12.95$ million to plaintiffs in a racial profiling lawsuit against the New Jersey State Police. ${ }^{178}$ Professors Marc Miller and Ronald Wright reported that although some of these settlements garner intense media attention, municipalities quietly settle many more lawsuits than people generally assume, the majority of which involve "secret settlements" that are filed under seal. ${ }^{179}$

There have been few evaluations of the impact of $\S 1983$ lawsuits on police misconduct. ${ }^{180}$ Criminologist Candace McCoy argues that federal lawsuits have led to improved police practices because of the unique role of insurance carriers. ${ }^{181}$ That is, in the wake of the Monell ruling, many law enforcement agencies sought to reduce their exposure to lawsuits by securing liability insurance. ${ }^{182}$ "But insurance companies would not offer attractively priced policies if police agencies could not demonstrate that they had done everything possible to reduce the risk of lawsuits." ${ }^{183}$ Insurance companies began devising risk management protocols for

\footnotetext{
175 Angelo N. Ancheta, Defendant Class Actions and Federal Civil Rights Litigation, 33 UCLA L. REV. 283, 298 (1985).

176 Jerome H. Skolnick \& James J. Fyfe, Above the Law: Police and the Excessive Use OF FORCE 202 (1993).

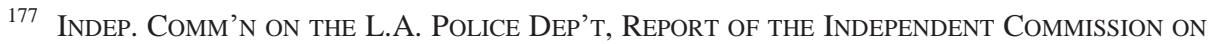
the Los ANGeles POLICE DEPARTMENT 56 (1991), http://michellawyers.com/wpcontent/uploads/2010/06/Report-of-the-Independent-Commission-on-the-LAPD-re-RodneyKing_Reduced.pdf.

178 Iver Peterson \& David M. Halbfinger, New Jersey Agrees to Pay \$13 Million in Profiling Suit, N.Y. TIMES (Feb. 3, 2001), http://www.nytimes.com/2001/02/03/nyregion/new-jersey-agrees-topay-13-million-in-profiling-suit.html.

179 Marc L. Miller \& Ronald F. Wright, Secret Police and the Mysterious Case of the Missing Tort Claims, 52 BufF. L. Rev. 757, 776 (2004).

180 In 1985, the U.S. Supreme Court established a national mandatory minimum requirement for the use of deadly force in Tennessee v. Garner, 471 U.S. 1 (1985). Abraham Tennenbaum examined the effects of the Garner decision on use of deadly force nationwide and concluded that it reduced the number of police killings by 60 homicides a year-a $16 \%$ decrease. Abraham N. Tennenbaum, The Influence of the Garner Decision on Police Use of Deadly Force, 85 J. CRIM. L. \& CRIMINOLOGY 241, 257 (1994).

181 Candace McCoy, How Civil Rights Lawsuits Improve American Policing, in Holding Police Accountable 111, 112 (Candace McCoy ed., 2010).

182 Id. at 144.

183 Id.
} 
police that specified mandates for training, policy, and supervision that met national standards. ${ }^{184}$ McCoy notes that $§ 1983$ litigation,

coupled with the professional risk management skills and oversight of the private insurance industry, have not been given the credit they deserve. This accountability device has probably been the source of the most far-reaching yet deep reforms in American policing over the past three decades. ${ }^{185}$

\section{B. Section 14141}

The U.S. Department of Justice (DOJ) also plays an important role in addressing police misconduct that violates citizens' federally protected civil rights. In 1994, Congress enacted 42 U.S.C. § 14141 as part of the Violent Crime Control and Law Enforcement Act. ${ }^{186}$ This law is often referred to as "the Rodney King Law" because Congress enacted it in the wake of widespread media broadcasts of videotaped footage of real and significant police brutality against Rodney King at the hands of Los Angeles Police Department officers. ${ }^{187}$ The statute provides as follows:

(a) Unlawful conduct

It shall be unlawful for any governmental authority, or any agent thereof, or any person acting on behalf of a governmental authority, to engage in a pattern or practice of conduct by law enforcement officers or by officials or employees of any governmental agency with responsibility for the administration of juvenile justice or the incarceration of juveniles that deprives persons of rights, privileges, or immunities secured or protected by the Constitution or laws of the United States.

(b) Civil action by Attorney General

Whenever the Attorney General has reasonable cause to believe that a violation of paragraph (1) has occurred, the Attorney General, for or in the name of the United States, may in a civil action obtain appropriate equitable and declaratory relief to eliminate the pattern or practice. ${ }^{188}$

184 Id. at $144-46$.

185 Id. at 150.

186 Pub. L. No. 103-322, 108 Stat. 1796 (1994) (codified in scattered sections of the U.S.C.).

187 See, e.g., David M. Jaros, Preempting the Police, 55 B.C. L. REv. 1149, 1159-60 (2014) (describing legislative action following the Rodney King beating); Stephen Rushin, Using Data to Reduce Police Violence, 57 B.C. L. REV. 117 (2016).

18842 U.S.C. § 14141 (2012). 
Unlike $\S 1983$, which provides a private right of action, $\S 14141$ authorizes the U.S. Attorney General to initiate structural reform litigation (SRL) against local police departments found to have engaged in systemic misconduct. ${ }^{189}$ The $\S 14141$ process begins with case selection, wherein the DOJ typically relies upon media reports, existing litigation, "whistleblowers" within police departments, academic reports, or information from other federal government agencies in order to identify departments who may be engaged in systematic misconduct. ${ }^{190}$ The Civil Rights Division conducts a preliminary inquiry to determine if the nature and extent of the alleged problem for a given department warrants a more thorough investigation. ${ }^{191}$ Based on the results of the preliminary investigation, a department may then be subjected to a formal inquiry by the Special Litigation Section of the Civil Rights Division (involving extensive internal investigation of a particular department that may take years and cost millions of dollars). ${ }^{192}$ If a pattern or practice of civil rights violations is found during the formal inquiry, the DOJ issues a technical assistance letter or an investigative findings letter that details the unconstitutional police practices and the evidence supporting the conclusions. ${ }^{193}$ The DOJ and the agency then begin settlement negotiations over reforms to be enacted to prevent official litigation in federal court. ${ }^{194}$ If the DOJ and the agency cannot negotiate a settlement, the DOJ files suit in federal court.

Successful negotiations between the DOJ and municipalities, either before or after a formal $\S 14141$ lawsuit is filed, typically lead to either a consent decree or memorandum of agreement. ${ }^{195}$ The consent decree outlines the remedies that must

189 Stephen Rushin, Structural Reform Litigation in American Police Departments, 99 MinN. L. REV. 1343, 1347 (2015).

190 Rushin, supra note 161, at 3220-24.

191 Id. at 3219-26.

192 Id. at 3224-29; see also Rushin, supra note 189, at 1370-71.

193 Rushin, supra note 161, at 3228-29; see also Rachel A. Harmon, Promoting Civil Rights Through Proactive Policing Reform, 62 STAN. L. REV. 1, 16 (2009).

194 Rushin, supra note 161, at 3228; see also POLICE EXEC. RESEARCH FORUM, supra note 161, at 27.

195 It is important to note that until relatively recently, settlements have been the norm, but this may be changing - perhaps as the defendants realize what it might cost to comply. Consider, for example, that Alamance, North Carolina, went to trial on a § 14141 claim and prevailed (although the DOJ is appealing). Michael D. Abernethy, Judge Dismisses DOJ Case Against Johnson, Finds No Evidence of Unconstitutional Practices, Times-News (Aug. 7, 2015), http://www.thetimesnews.com/article/20150807/NEWS/150809283. Ferguson, Missouri originally participated in negotiations for a consent decree, but subsequently withdrew from the agreement. Matt Ford, United States v. Ferguson: Attorney General Loretta Lynch Announced the Justice Department is Suing the Missouri Municipality After an Agreement on Reform Broke Down, ATLANTiC (Feb. 11, 2016), http://www.theatlantic.com/politics/archive/2016/02/doj-fergusonlawsuit/462300/. As a result, DOJ filed suit against Ferguson in February 2016; as of this writing, Ferguson contests the substantive allegations that the municipality has engaged in "a pattern or 
be implemented to address the unconstitutional behavior by officers. The DOJ and the municipality select an external monitor to oversee the agency's progress towards achieving compliance with the consent decree. ${ }^{196}$

A consent decree is typically designed to last five years, though federal oversight often lasts much longer. For example, the Los Angeles Police Department was under consent decree for nine years. The Detroit Police Department was under consent decree for nearly 14 years. And some agencies, such as the Cleveland Division of Police, have been under consent decree twice. Since 1994, the DOJ has initiated approximately 55 formal inquiries of law enforcement agencies under the authority of $\S 14141$, leading to 24 settlements or consent decrees. ${ }^{197}$

Most $\S 14141$ consent decrees have targeted unconstitutional patterns or practices involving use of force and racially discriminatory policing in stops, searches, and arrests. Consent decrees include a wide range of remedies that address policies, procedures, training, supervision, implementation of early intervention/risk management systems, enhanced data collection and analysis, more robust citizen complaint procedures, and adoption of community outreach/community-oriented policing initiatives. ${ }^{198}$

There are very few evaluations of $\S 14141$ consent decrees. A Vera Institute of Justice study from 2005 by Davis, Henderson, and Ortiz assessed the sustainability of consent decree reform efforts one year after the termination of the consent decree for the Pittsburgh Bureau of Police. ${ }^{199}$ Kupferberg examined data on the Los Angeles Police Department (LAPD), the New Jersey State Troopers, and the New York City Police Department (Daniels case) to assess whether the consent decrees for each department affected racial disparities in stops, arrests, and other types of police activity. ${ }^{200}$ Schatmeier identified key features associated with

practice of law enforcement conduct that violates the Constitution and federal civil rights laws" and is, therefore, actively defending the litigation. Id.

196 Police Exec. Research Forum, supra note 161, at 29-31.

197 Rushin, supra note 161, at 3247; Rushin, supra note 189, at 1377; see also Darrell L. Ross \& Patricia A. Parke, Policing by Consent Decree: An Analysis of 42 U.S.C. \& 14141 and the New Model for Police Accountability, 10 Police Prac. \& REs. 199, 200 (2009). For additional insight into the consent decree process, see SAmuel Walker \& Carol A. Archbold, The NeW World of Police Accountability 25-26 (2d ed. 2014); Michael D. White, Preventing Racially Biased Policing Through Internal and External Controls: The Comprehensive Accountability Package, in Race, Ethnicity, and Policing: New and Essential Readings 468, 480 (Stephen K. Rice \& Michael D. White eds., 2010); Debra Livingston, Police Reform and The Department of Justice: An Essay on Accountability, 2 BUFF. CRIM. L. REV. 815 (1999).

198 See Rushin, supra note 189, at 1383-84, 1401-03; Police EXEC. RESEARCH Forum, supra note 161, passim.

199 Robert Davis, Nicole Henderson \& Christopher Ortiz, Can Federal Intervention Bring Lasting Improvement in Local Policing?: The Pittsburgh Consent Decree 4 (2005), http://www.vera.org/sites/default/files/resources/downloads/277_530.pdf.

200 Noah Kupferberg, Transparency: A New Role for Police Consent Decrees, 42 Colum. J.L. \& Soc. Probs. 129, 129 (2008). 
the implementation of the consent decree for the Cincinnati Police Department. ${ }^{201}$ Stone, Foglesong, and Cole evaluated the LAPD's consent decree using observational methods, focus groups, and quantitative analysis of administrative data. $^{202}$ Chanin conducted a longitudinal analysis to assess whether consent decree reforms were associated with sustainable change in citizen complaints, police use of force incidents, and civil litigation in Cincinnati, Pittsburgh, and the District of Columbia. ${ }^{203}$ Chanin also examined data from stakeholder interviews and monitor reports to assess the implementation of consent decrees in Pittsburgh, Detroit, Washington, D.C., Cincinnati, and Prince George's County, Maryland. ${ }^{204}$

A number of themes emerge from a close reading of this handful of consent decree studies. First, officers view consent decrees skeptically, and federal oversight negatively affects officer morale. ${ }^{205}$ Second, though officers frequently suggested that the consent decree led to less proactive police work, results from several studies showed increased levels of summons, stops, and arrests during the consent decree. ${ }^{206}$ Third, there is modest evidence that both use of force ${ }^{207}$ and citizen complaints ${ }^{208}$ decrease during consent decrees, though research has not demonstrated that excessive or unlawful force declined during federal oversight. Fourth, there is also some evidence to suggest that public satisfaction with police increases as a result of consent decrees. ${ }^{209}$ Alternatively, several studies have shown that racial disparities in stops and arrests persisted despite federal oversight. $^{210}$ The dearth of research on consent decrees and their impact is troubling given their significant cost. For example, the consent decree for the LAPD is estimated to have cost between $\$ 30$ and \$50 million annually (totaling

201 Elliot Harvey Schatmeier, Reforming Police Use-of-Force Practices: A Case Study of the Cincinnati Police Department, 46 Colum. J.L. \& Soc. Probs. 539, 539 (2013).

202 Christopher Stone, Todd Foglesong \& Christine M. Cole, Policing Los Angeles Under a Consent Decree: The Dynamics of Change AT the LAPD (2009), http://www.lapdonline.org/assets/pdf/Harvard-LAPD\%20Study.pdf.

203 Joshua M. Chanin, Examining the Sustainability of Pattern or Practice Police Misconduct Reform, 18 Police Q. 163, 163 (2015).

204 Joshua Chanin, On the Implementation of Pattern or Practice Police Reform, 15 CRiminology, CRIM. JUST., L. \& SOC'Y 38, 38 (2014).

205 See DAvis, Henderson \& OrTIZ, supra note 199; Schatmeier, supra note 201; STONE, FOGLESONG \& COLE, supra note 202, at 6.

206 See DAVIs, Henderson \& OrTIZ, supra note 199; Kupferberg, supra note 200, at 151-52, 154-55, 158-59; STONE, FogLeSONG \& Cole, supra note 202, at i.

207 See Chanin, supra note 203, at 165; Schatmeier, supra note 201, at 560; STONE, FogLESONG \& COLE, supra note 202, at 1.

208 See Chanin, supra note 203, at 183; DAVIS, HeNDERson \& ORTIZ, supra note 199, at 42.

209 See DAVIS, HENDERSON \& ORTIZ, supra note 199, at 35, 38; Schatmeier, supra note 201, at 563; Stone, Foglesong \& Cole, supra note 202, i-ii.

210 See Kupferberg, supra note 200; STONE, Foglesong \& ColE, supra note 202, at ii. 
\$250 million over five years), and the Cincinnati Police Department consent decree entailed \$13 million in start-up costs alone. ${ }^{211}$

\section{Federal Civil Litigation over the NYPD's Stop-and-Frisk Program}

The widespread deployment stop-and-frisk by the NYPD resulted in two major § 1983 lawsuits alleging racial profiling. In 1999, the Center for Constitutional Rights (CCR) filed a class action lawsuit against the NYPD, Daniels v. City of New York, alleging that NYPD officers were selectively targeting individuals on the basis of their race and national origin, without reasonable suspicion, in violation of the Fourth and Fourteenth Amendments to the U.S. Constitution. ${ }^{212}$ Of particular concern was the NYPD's Street Crime Unit (SCU), a plainclothes unit comprised of more than 300 officers, several of whom were responsible for killing Amadou Diallo in February 1999. ${ }^{213}$ The death of Diallo ignited citywide demonstrations against police brutality, and the SCU unit was eventually disbanded in 2002. ${ }^{214}$ In September 2003, the NYPD and CCR agreed to settle the civil suit through an out-of-court consent decree approved by Judge Shira Scheindlin (who would eventually preside over the Floyd case). ${ }^{215}$ As part of the consent decree, the NYPD agreed to: maintain a written anti-racial profiling policy; train officers on legal issues in stop-and-frisk (and cultural diversity); require that officers record stop data on a UF-250 form; conduct audits of the UF-250 forms; and maintain an electronic database of stops (based on the UF-250 forms) that would be provided quarterly to plaintiffs. ${ }^{216}$

The Daniels settlement did not include an independent monitor, and the evidence suggests that the NYPD's compliance with the consent decree was

211 Ross \& Parke, supra note 197, at 204; Samuel Walker, The New Paradigm of Police Accountability: The U.S. Justice Department "Pattern or Practice" Suits in Context, 22 ST. LoUIS U. Pub. L. ReV. 3, 49 (2003).

212 Stipulation of Settlement at 1-2, Daniels v. City of New York, No. 99 Civ. 1695 (S.D.N.Y. Sept. 24, 2003) [hereinafter Daniels Settlement].

213 See Michael Cooper, Officers in Bronx Fire 41 Shots, and an Unarmed Man Is Killed, N.Y. Times, Feb. 5, 1999, at Al.

214 Kupferberg, supra note 200, at 142 (citing Ginger Thompson, 1,000 Rally to Condemn Shooting of Unarmed Man by Police, N.Y. Times, Feb. 8, 1999, at B1; Kevin Flynn, Police Killing Draws National Notice, N.Y. Times, Feb. 8, 1999, at B5; Andy Newman, Prayer in New York, Protest in Washington, N.Y. TIMES, Feb. 16, 1999, at B5).

215 See Current Developments, City Torts: Wrongful Death: City Settled Diallo Suit, 10 CiTY L. 43 (2004).

216 Daniels Settlement, supra note 212, at 5. The year after the Daniels settlement, New York City enacted a law codifying a provision of the settlement by prohibiting "the use of race, color, ethnicity, religion or national origin as the determinative factor for initiating police action." Kupferberg, supra note 200, at 156. 
mixed, at best. ${ }^{217}$ As a result, the CCR filed a second class-action lawsuit against the NYPD in 2008, Floyd v. City of New York, ${ }^{218}$ as well as a new companion case in Daniels. ${ }^{219}$ The Floyd case proceeded to trial in early 2013, again under Judge Shira Scheindlin. The allegations against the NYPD were supported by the expert reports of Criminologist Jeffrey Fagan, ${ }^{220}$ as well as analyses carried out by CCR. ${ }^{221}$ Fagan's expert reports in the Floyd case analyzed the NYPD's stop-andfrisk data from 2004 through 2009, and from January 2010 through June 2012. After controlling for crime, neighborhood context, and the concentration of police officers in specific areas, Fagan found that Blacks and Latinos were still disproportionately targeted by the NYPD's stop-and-frisk program, in support of the plaintiff's Fourth and Fourteenth Amendment claims (see Table 1). ${ }^{222}$

217 For a detailed discussion of the shortcomings of the Daniels settlement and its implementation, see Kupferberg, supra note 200, at 144-45, 155-58.

218 Complaint and Demand for Jury Trial, Floyd v. City of New York, 08 Civ. 1034 (S.D.N.Y. Jan. 31, 2008), http://ccrjustice.org/files/Floyd_Complaint_08.01.31.pdf.

219 Daniels v. City of New York, No. 99 Civ. 1695, 2007 WL 2077150, at *3 (S.D.N.Y. July 16, 2007).

220 Report of Jeffrey Fagan, Ph.D. at 1-2, Floyd v. City of New York, 08 Civ. 1034 (S.D.N.Y. Oct. 15, 2010) [hereinafter https://ccrjustice.org/files/Expert_Report_JeffreyFagan.pdf; Second Supplemental Report of Jeffrey Fagan, Ph.D. at 1-2, Floyd v. City of New York, 08 Civ. 1034 (S.D.N.Y. Nov. 29, 2012) [hereinafter Fagan Second Supplement Report], http://www.ccrjustice.org/files/FaganSecondSupplementalReport.pdf.

221 CTR. FOR CONSTitutional Rights, Racial DisParity IN NYPD STOPS-AND-Frisks: The Center for Constitutional Rights Preliminary Report on UF-250 DATA From 2005 Through JUNE 20084 (2009), https://ccrjustice.org/files/Report-CCR-NYPD-Stop-and-Frisk.pdf.

222 Fagan Report, supra note 220, at 3-4; Fagan Second Supplemental Report, supra note 220, at $2-6$. 
Table 1. Summary of Dr. Jeffrey Fagan's Statistical Findings

for the Floyd Litigation

Fourth Amendment Claims

- Nearly 150,000 , or $6.71 \%$ of all discretionary stops lack legal justification. An additional 544,252 , or $24.37 \%$ of all discretionary stops lack sufficiently detailed documentation to assess their legality.

- Officers rely heavily on two constitutionally problematic stop justifications for nearly half of all stops: furtive movements and proximity to a high crime area.

- Documented stop justifications do little to explain overall variations in stop patterns and do not substantially influence the racial disparities that characterize stop practices between police precincts.

- The rate of gun seizure is $0.15 \%$, or nearly zero, and arrests take place in less than $6 \%$ of all stops.

- Black and Hispanic suspects are treated more harshly once the decision is made that a crime has occurred. Black and Hispanic suspects are more likely to be arrested than issued a summons when compared to White suspects. They are more likely to be subjected to use of force.

Fourteenth Amendment Claims

- NYPD stop activity is concentrated in precincts with high concentrations of Black and Hispanic residents even after controlling for the influences of crime, social conditions, and the allocation of police resources.

- NYPD stops are significantly more frequent for Black and Hispanic citizens than for white citizens, even after adjusting for precinct crime rates, the racial composition, and other social and economic factors predictive of police activity.

- Black and Hispanics are more likely to be stopped than whites even in areas where there are low crime rates and where residential populations are racially heterogeneous or predominantly White.

In August 2013, Judge Scheindlin ruled that the NYPD was engaging in unconstitutional stop-and-frisk practices that targeted predominately Black and Latino New Yorkers. ${ }^{223}$ In a separate decision, Judge Scheindlin ordered several remedies to address the NYPD's racially discriminatory stop-and-frisk program. ${ }^{224}$ She appointed an independent monitor to oversee compliance with the remedies, which included reformation of policies, training, supervision, documentation, and disciplinary action, as well as the publication of monitor reports that detail the

223 Floyd v. City of New York, 959 F. Supp. 2d 540 (S.D.N.Y. 2013) (liability decision).

224 Floyd v. City of New York, 959 F. Supp. 2d 668, 669 (S.D.N.Y. 2013) (remedy decision). 
NYPD's compliance with the ordered reforms. ${ }^{225}$ Judge Scheindlin also ruled that the citizens most affected by stop-and-frisk should play a role in the reforms, and that the NYPD begin a one-year pilot study of body-worn cameras in the seventyfifth precinct. ${ }^{226}$

Events continued to unfold in New York City in the months following the landmark Floyd ruling. First, the City appealed Judge Scheindlin's ruling to the U.S. Court of Appeals for the Second Circuit and sought a stay of her remedies, pending the outcome of the appeal. The appellate court granted the City's motion for a stay pending appeal. ${ }^{227}$ The Second Circuit also determined that Judge Scheindlin had failed to avoid the appearance of impartiality and therefore ordered her removal from the case. ${ }^{228}$ Importantly, though, the Second Circuit did not overturn the substance of Judge Scheindlin's rulings.

Second, several police unions filed motions to intervene in the appeal alleging that Judge Scheindlin had erred in her interpretations of evidence and the law. ${ }^{29}$ The police union motions were denied on multiple grounds, including being untimely, and the unions having "no significant protectable interests relating to the subject of the litigation that would warrant intervention." 230

Third, the NYPD's stop-and-frisk program (and the Floyd case) became a defining feature of the New York City mayoral election in fall 2013. In effect, the mayoral election became a referendum on stop-and-frisk, and mayoral candidate William de Blasio was elected in part because of his opposition to the NYPD stopand-frisk program. Upon taking office, Mayor de Blasio replaced NYPD Commissioner Raymond Kelly with former Commissioner William Bratton. Commissioner Bratton pledged to address NYPD reform through the inclusion of "more oversight and training . . . [and] more guidance." 231 In January 2014, the Mayor pledged to drop the City's appeal of the Floyd ruling, though it was not officially dropped until October $2014 .^{232}$ Since then, the City and Commissioner Bratton have been working to implement the remedies ordered in Judge

225 Id. at 675-90.

226 Id. at 684-86.

227 Ligon v. City of New York, 538 Fed. Appx. 101 (2d Cir. 2013).

228 Id. at 102-103.

229 Opposition of Sergeants Benevolent Association to Motion of City of New York for Limited Remand to the District Court for the Purpose of Exploring a Resolution at 1-2, Floyd v. City of New York, No. 13-3088 (2d Cir. Feb. 7, 2014), http://ccrjustice.org/files/SBA\%20Opp\%20to\%20City\%27s\%20Motion\%20to\%20Remand.\%202\%2 07\%202014.pdf.

230 Floyd v. City of New York, 302 F.R.D. 69, 76 (S.D.N.Y. 2014).

231 Azi Paybarah, Bill Bratton: There Will Always Be Stop-and-Frisk, Politico (June 14, 2013, 12:16 PM), http://www.politico.com/states/new-york/city-hall/story/2013/06/bill-bratton-therewill-always-be-stop-and-frisk-000000.

232 Floyd v. City of New York, 770 F.3d 1051 (2d Cir. 2014) (granting City of New York's motion for voluntary dismissal of the appeals with prejudice). 
Scheindlin's original ruling, including a joint remedial process that will "develop a set of reforms with the direct input of the people most affected by the NYPD's discriminatory stop-and-frisk practices." 233

\section{The Current Study}

Though federal civil litigation has become one of the primary mechanisms for addressing widespread unconstitutional policing, there have been very few empirical examinations of the effectiveness of such litigation. The lack of evaluative work on the impact of federal civil litigation has left the mechanism vulnerable to criticism, ${ }^{234}$ and has raised questions about the proper role of the federal government in overseeing local law enforcement practices (i.e., federalism). ${ }^{235}$ As a result, we have little understanding of the role that federal civil litigation has played in police reform to date, or its potential to effect change and reduce unconstitutional policing in the 21st century. Given the gravity of the constitutional violations, as well as the implications and cost for local law enforcement agencies, the lack of knowledge regarding the effectiveness of federal civil litigation is concerning.

Dr. Fagan's analyses in the Floyd case demonstrate that the stipulations of the original Daniels settlement had little effect on the manner in which the NYPD executed stop-and-frisk activities between 2005 and 2012. In the wake of the Floyd ruling, however, significant events transpired as a result of the litigation and the accompanying federal court oversight. The current study descriptively examines the impact of the Floyd case on the nature and prevalence of NYPD stops, through a comparison of stop activity and outcomes from 2011 (when the program was at its height) and 2014 (the year after the Floyd ruling).

\section{METHODS}

\section{A. Data}

To determine whether the litigation in Floyd positively influenced stop-andfrisk activities by the NYPD, the authors compare and contrast official stop-andfrisk data from 2011 and 2014 as recorded by officers on UF-250 forms. The data are drawn from the NYPD's Stop, Question, and Frisk Report Database, which is

\footnotetext{
233 Joint Remedial Process in Floyd v. City of New York: What You Need to Know, CTR. FOR Constitutional Rights (June 23, 2014), https://web.archive.org/web/20160413131113/https://ccrjustice.org/home/get-involved/toolsresources/fact-sheets-and-faqs/timeline-floyd-v-city-new-york.

234 McCoy, supra note 181; Ross \& Parke, supra note 197.

235 Samuel P. Jordan, Federalism, Democracy, and the Challenge of Ferguson, 59 ST. LouIS U. L.J. 1103, 1103 (2015).
} 
publicly available online. The data are available as both a portable file and a comma separated values (CSV) file. For the descriptive analyses presented here, the portable files were used in conjunction with SPSS Version 22, whereas the CSV files were used to create a map in ArcGIS 10.2.

Officers are mandated to fill out a UF-250 form if a police officer uses force, the person stopped refuses to identify him or herself, or the individual stopped is frisked, searched, and/or arrested. ${ }^{236}$ The following information is found on a UF250 form:

- The suspect's sex, race, age, height, weight, hair color, eye color, and other features such as scars and tattoos.

- The location of the stop, including address number, street name, intersection, city, state, zip code, police beat, police section, and police borough, along with the longitudinal (X) and latitudinal (Y) coordinates.

- The reason or reasons that led up to the stop, frisk, and/or search.

- The reason for police use of force and the type of force employed.

- Whether the suspect was frisked, searched, and/or arrested.

- Whether contraband or a weapon was found on the suspect. ${ }^{237}$

\section{B. Analytic Strategy}

The authors explore five research questions using NYPD stop-and-frisk data from 2011 and 2014:

1. How has the prevalence of stop-and-frisk changed from 2011 to 2014 ?

2. Has the geographic concentration of stop-and-frisk changed notably from 2011 to 2014?

3. Has the nature of what transpires during stops changed notably from 2011 to 2014 (i.e., frisks, searches, arrests, weapons and contraband seized)?

4. Have the racial disparities among those subjected to stop-and-frisk changed notably from 2011 to 2014?

5. Have crime trends in New York City changed in the wake of pressure to reform the stop-and-frisk program (post-Floyd ruling)?

236 SPITZER, supra note 13, at 63-64.

237 For a complete list of information listed by police officers on UF-250 forms, see NYPD StOP-AND-FRISK DATABASE, supra note 20, Database File Specifications. 
To address these research questions, the authors first examine the prevalence of NYPD stops annually from 2003 through 2014. Second, the authors identify the geographic locations of all stops in 2011 and 2014, at the precinct level, and examine the percent change in stop locations pre- and post-Floyd ruling. This analysis is of particular interest because the Fagan analyses in the Floyd case demonstrated that NYPD stop activity disproportionately targeted neighborhoods and precincts where the majority of residents were ethnic minorities. The analyses here will assess whether the racially geographic concentration of stops has persisted post-Floyd ruling. Third, Fagan's analyses in the Floyd case demonstrated that not only were minorities more likely to be stopped, they were also disproportionately likely to be subjected to frisk, search, and arrest. The authors descriptively compare stop outcomes both overall, and by citizen race/ethnicity, to determine whether the racial disparity finding has persisted in the wake of the Floyd ruling. Fourth, as an indicator of the effectiveness of stops, the authors compare the rates at which stops produce guns, other weapons, and contraband pre- and post-Floyd ruling. Finally, the authors explore trends in violent and property crime rates, as well as total homicides, through 2014 to determine whether reforms in stop-and-frisk (if they occurred) may be associated with changes in crime in New York.

The current study does suffer from several limitations that should be acknowledged. First, the current study presents a descriptive year-to-year comparison only, which restricts statements about causality between the federal civil litigation and changes in stop-and-frisk practices. Second, the findings are based on NYPD administrative data, and several critics have suggested that the UF-250 data may not be complete and accurate. In fact, there are indications that a substantial proportion of stops occur without formal documentation. Consider that Jones-Brown and colleagues reported that although one study estimated that approximately $70 \%$ of all stops were captured on UF-250 forms, an NYPD commander estimated that "only 1 in 10 stops" was documented by officers on the UF-250. ${ }^{238}$ Finally, the earlier discussion demonstrates that a number of events after the Floyd ruling may have shaped the NYPD's stop-and-frisk program including media attention, a new mayor, and a new police commissioner-though many of these events are directly related to the Floyd ruling. Results should be interpreted in the context of these limitations.

238 Delores Jones-Brown, Brett G. Stoudt, Brian Johnston \& Kevin Moran, Stop, Question and Frisk Policing Practices in New York City: A Primer (Revised) 3 (July 2013), http://www.atlanticphilanthropies.org/app/uploads/2015/09/SQF_Primer_July_2013.pdf; see also Weisburd et al., supra note 129, at 148; Rosenfeld \& Fornango, supra note 152, at 98. 


\section{RESULTS}

\section{A. Stop Counts and Geographic Concentration ${ }^{239}$}

Figure 1 illustrates that the number of stops has dropped precipitously since peaking at 685,724 in 2011. The number declined by 22\% in 2012 (to 532,911 stops), and by another 64\% in 2013 (191,851 stops). In 2014, the NYPD recorded just 45,788 stops, a 93\% decrease from 2011 - the peak of the program just three years earlier. In terms of the Floyd case, the number of stops declined before the case went to trial in early 2013. But the litigation had been pending since 2008, and the pressure on the NYPD regarding the stop-and-frisk program was enormous in the years leading up to the court case. It is reasonable to assert an association between the Floyd case-as well as the attention it garnered-and the substantial decline in stop-and-frisk that began in 2012. Certainly, the change in mayor and police commissioner in early 2014 - and their highly publicized decision to drop the Floyd appeal and curtail the stop-and-frisk program-explains the continued decline in 2014.

Figure 1. NYPD Stop Data by Year

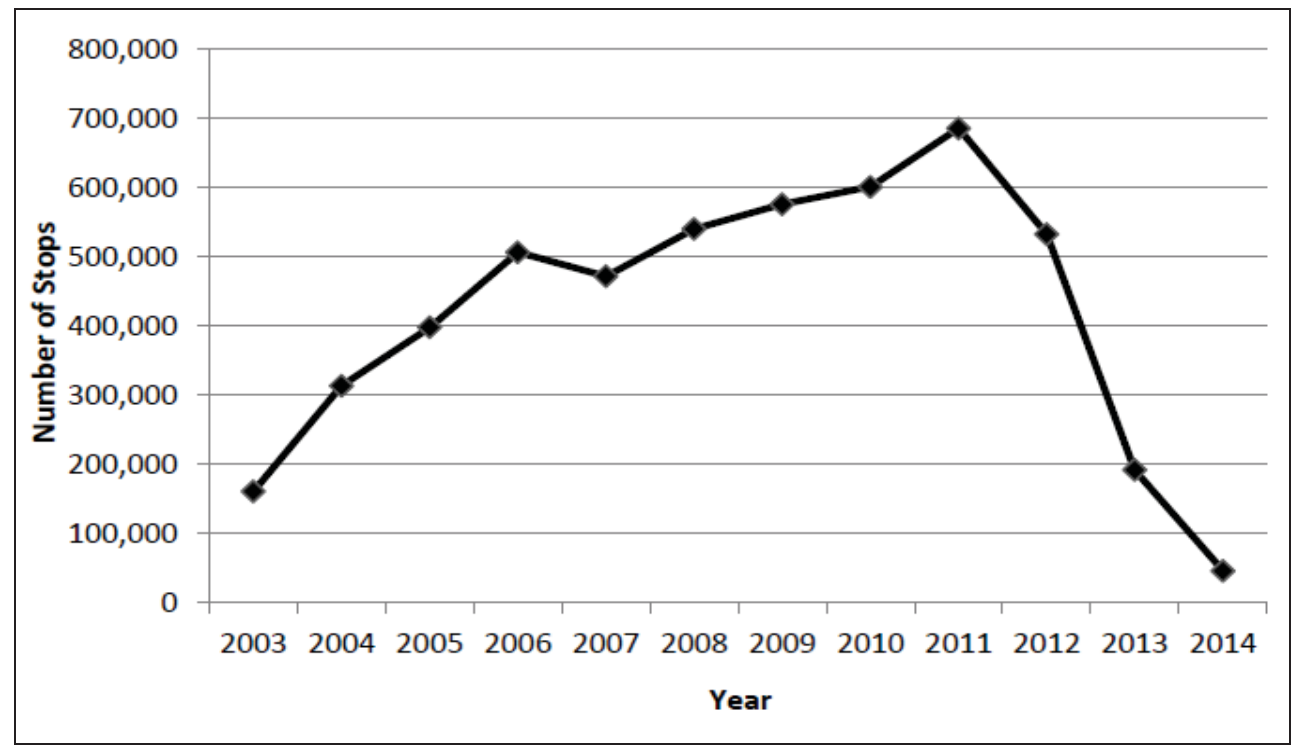

239 The results reported in this section, including those contained in tables and figures, come from our own analyses of the raw data reported in the official NYPD STOP-AND-FRISK DATABASE, supra note 20. 
Figure 2 illustrates the degree of change in the concentration of stop-and-frisk activity from 2011 to 2014. ${ }^{240}$ Although every NYPD precinct experienced a significant decline in the overall number of stops, some precincts did experience an increase in their proportion of the total number of stops, from 2011 to 2014 (darker shades, such as the 122nd and 123rd precincts). Overall, 44 of the 76 precincts experienced a decline in their proportion of the total percentage of stops (reflected by the lighter shades). Moreover, that decrease was particularly notable in precincts that had previously been disproportionally affected by racially disparate stop-and-frisk activities.

Figure 2. Stop Composition by Precincts

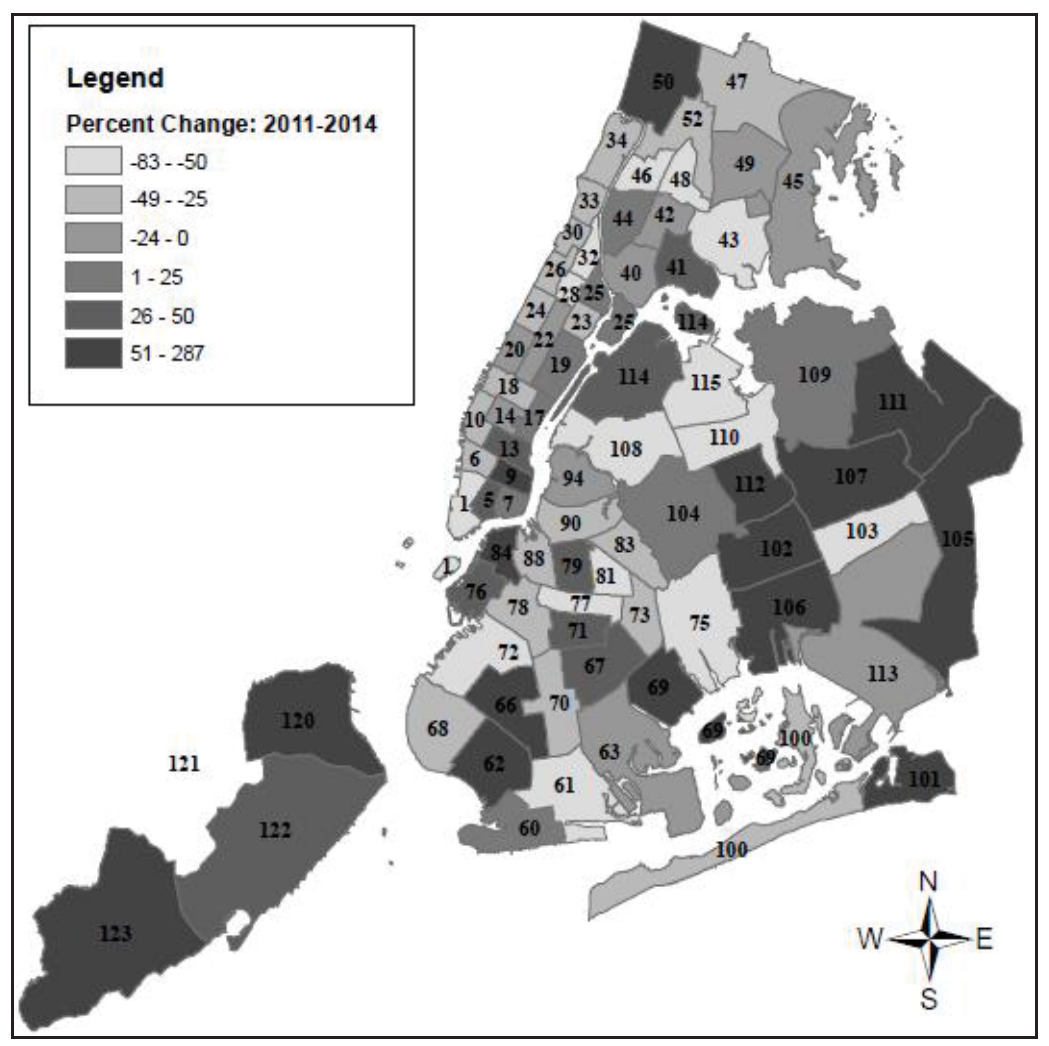

240 NYPD STOP-AND-FrisK DATABASE, supra note 20. Note that the 121st precinct was excluded from the map because it did not contain stop data in 2011 for a comparison to be made against 2014. 
Table 2 illustrates the finding in a different way. Prior research indicates that ten precincts with large minority populations have experienced a disproportionate share of stop-and-frisks. ${ }^{241}$ Those precincts include:

- $\quad$ 23rd - East Harlem (south)

- $\quad$ 40th - Mott Haven, Melrose

- $\quad$ 44th - Concourse, Highbridge

- $\quad$ 73rd - Ocean Hill, Brownsville

- $\quad$ 75th - East New York, Starret City

- $\quad$ 77th - Crown Heights (north), Prospect Heights

- $\quad$ 79th - Bedford-Stuyvesant (west)

- $\quad$ 103rd - Jamaica (south), Hollis

- $\quad$ 115th - Jackson Heights

- $\quad$ 120th - St. George, West Brighton, Port Richmond

In 2011, these ten precincts were responsible for $27.13 \%$ of all stops in New York, ranging from $1.66 \%$ to $4.53 \%$ of the total percentage of stops (77th and 75th precincts, respectively). Table 2 shows that the same ten precincts were responsible for just $19.68 \%$ of all stops in 2014. Moreover, seven of the ten precincts experienced a decline in the percentage of total stops, with five of the precincts experiencing drops of nearly 50\% or more. For example, in the Floyd ruling Judge Scheindlin singled out the 75th precinct for its misuse of stop-andfrisk, and she selected it as the location for the body-worn camera pilot study. In 2011, the 75th precinct was responsible for $4.53 \%$ of the total stops that year. By 2014, the 75th precinct was responsible for just $2.0 \%$ of all stops, representing a decline of $55.85 \% .{ }^{242}$ In sum, the concentration of stop-and-frisk activity in mostly minority precincts has declined considerably following the Floyd ruling.

241 Jones-Brown, StOUdt, Johnston \& Moran, supra note 238, at 41-42.

242 NYPD STOP-AND-FRISK DATABASE, supra note 20. 
Table 2. Stop Percentages among Precincts with Large Minority Populations

\begin{tabular}{|c|c|c|c|c|c|}
\hline \multirow{2}{*}{ Precinct } & \multicolumn{2}{|c|}{$\begin{array}{c}2011 \\
(n=685,724)\end{array}$} & \multicolumn{2}{|c|}{$\begin{array}{c}2014 \\
(n=45,788)\end{array}$} & \multirow[t]{2}{*}{$\begin{array}{c}\text { Percent } \\
\text { Change } \\
2011-2014\end{array}$} \\
\hline & \# stops & $\begin{array}{c}\% \text { of } \\
\text { total stops }\end{array}$ & \# stops & $\begin{array}{c}\% \text { of } \\
\text { total stops }\end{array}$ & \\
\hline 23 & 17,498 & 2.55 & 719 & 1.57 & -38.43 \\
\hline 40 & 17,690 & 2.58 & 898 & 1.96 & -24.03 \\
\hline 44 & 16,903 & 2.46 & 1,330 & 2.9 & 17.89 \\
\hline 73 & 25,167 & 3.67 & 866 & 1.89 & -48.50 \\
\hline 75 & 31,100 & 4.53 & 917 & 2.00 & -55.85 \\
\hline 77 & 11,405 & 1.66 & 373 & 0.81 & -51.20 \\
\hline 79 & 14,498 & 2.11 & 1,452 & 3.17 & 50.24 \\
\hline 103 & 17,152 & 2.50 & 325 & 0.71 & -71.60 \\
\hline 115 & 18,156 & 2.65 & 205 & 0.45 & -83.02 \\
\hline 120 & 16,490 & 2.40 & 1,934 & 4.22 & 75.83 \\
\hline Total & 186,059 & $27.13 \%$ & 9,019 & $19.68 \%$ & \\
\hline
\end{tabular}




\section{B. Stop Outcomes: Frisks, Searches, Arrests, Weapons and Contraband}

After a stop occurs, law enforcement officers may take any number of subsequent actions - such as frisking a suspect, conducting a full-blown search of the suspect, placing the suspect under arrest, and seizing guns, other weapons and contraband-depending on the totality of the facts and circumstances they encounter. ${ }^{243}$ Arguably, any increases in the outcomes of post-stop events could signal improvements in stop activity, as officers are more accurately assessing reasonable suspicion of criminal activity. Their more accurate assessments of reasonable suspicion then lead to more formal outcomes, such as searches, arrests, and confiscation of weapons and contraband.

Figure 3 illustrates that since 2011, frisks, searches, and arrests have all occurred with greater frequency. Frisks increased from approximately $55.7 \%$ to $66.3 \%$, searches increased from $8.5 \%$ to $15.9 \%$, and arrests more than doubled, from $6.0 \%$ in 2011 to $15.1 \%$ in $2014 .{ }^{244}$ One of the most important criticisms of the NYPD's stop-and-frisk program was the low rate for recovering weapons and contraband, as demonstrated by the 2011 figures in Table 3. For example, in 2011 only $0.12 \%$ of stops resulted in seizure of a firearm and $1.1 \%$ resulted in seizure of another type of weapon. The seizure rates remain low in 2014, but in each case, the percent increase from 2011 is notable. For example, gun seizures increased from $0.12 \%$ of all stops to $0.44 \%$ - an increase of $267 \%$. Seizures of other weapons and contraband increased by $185 \%$ and $104 \%$, respectively. Given the more than $90 \%$ drop in the total number of stops, these data demonstrate that NYPD stop-and-frisk activity improved notably in terms of efficiency and accuracy from 2011 to 2014.

243 See generally FERdico, FradeLLA \& TotTEn, supra note 8, at 307-58.

244 NYPD STOP-AND-FRISK DATABASE, supra note 20. 
Figure 3. Frisk, Search, and Arrest Percentages

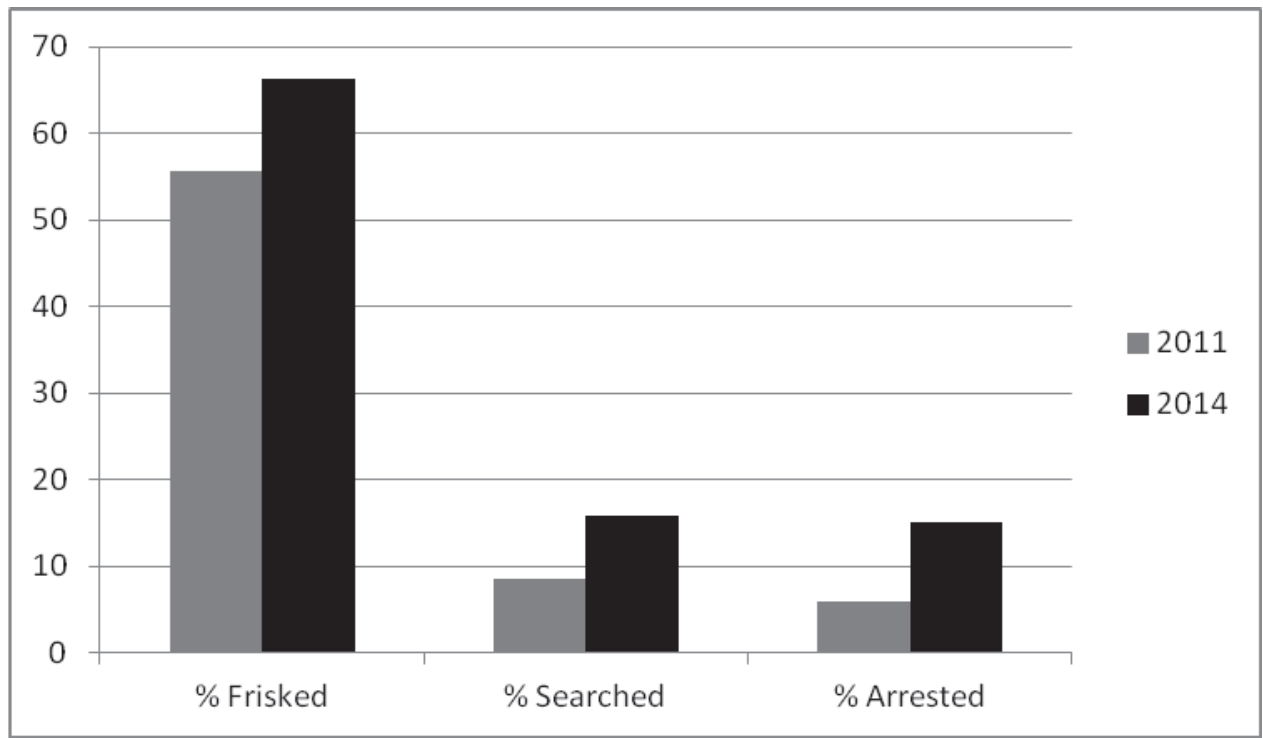

Table 3. Percentage of Weapons and Contraband Seizure

\begin{tabular}{|c|c|c|c|c|c|}
\hline \multirow{2}{*}{$\begin{array}{l}\text { Found } \\
\text { During } \\
\text { Search }\end{array}$} & \multicolumn{2}{|c|}{$\begin{array}{c}2011 \\
(n=685,724)\end{array}$} & \multicolumn{2}{|c|}{$\begin{array}{c}2014 \\
(n=45,788)\end{array}$} & \multirow{2}{*}{$\begin{array}{c}\text { Percent } \\
\text { Change } \\
2011- \\
2014\end{array}$} \\
\hline & Percentage & $\begin{array}{c}\text { Total } \\
\text { number }\end{array}$ & Percentage & $\begin{array}{l}\text { Total } \\
\text { Number }\end{array}$ & \\
\hline Knives/other & $1.1 \%$ & 7,444 & $3.13 \%$ & 1,431 & $185 \%$ \\
\hline Guns & $0.12 \%$ & 819 & $0.44 \%$ & 202 & $267 \%$ \\
\hline Contraband & $1.7 \%$ & 11,803 & $3.46 \%$ & 1,585 & $104 \%$ \\
\hline
\end{tabular}




\section{Stop, Frisk, and Racial Disparities}

The court ruled in the Floyd case that the NYPD unconstitutionally targeted young Black and Latino citizens, in violation of their Fourth and Fourteenth Amendment rights. Table 4 assesses the extent to which racial disparities persisted in stop-and-frisk activity after the court ruling, and unlike the findings on prevalence, geographic concentration, and outcomes, there appears to be little change in the racial make-up of those subjected to stop-and-frisk. ${ }^{245}$ For example, racial/ethnic make-up of citizens stopped in 2011 and 2014 are virtually identical: Black (51.1\%-53.1\%), Black-Hispanic (7.1\%-6.1\%), White-Hispanic (25.6\%$21.2 \%)$, White $(9.0 \%-11.9 \%)$, and other (7.2\%-7.7\%). The ethnic and racial make-up among those frisked changed slightly in 2014, but changes were $5 \%$ or less (frisks of Black citizens increased by about 3\% and frisks of White-Hispanic citizens decreased by 5.5\%). Similar stability is seen among those searched and arrested. In sum, the racial disparities among those subjected to stop-and-frisk by NYPD officers has changed little since the Floyd ruling.

245 NYPD STOP-AND-Frisk DATABASE, supra note 20. Note that the race/ethnicity categories of Asian/Pacific Islander, American Indian/Alaskan Native, and other were all collapsed into a single category entitled "other" because of their small sample size. 
Table 4. Racial and Ethnic Composition of Stops, Frisks, Searches \& Arrests

\begin{tabular}{|l|c|c|}
\hline Variable Description & $\mathbf{2 0 1 1}$ & $\mathbf{2 0 1 4}$ \\
\hline Stop Percentage & $51.1 \%$ & $53.1 \%$ \\
Black & $7.1 \%$ & $6.1 \%$ \\
Black-Hispanic & $25.6 \%$ & $21.2 \%$ \\
White-Hispanic & $9.0 \%$ & $11.9 \%$ \\
White & $7.2 \%$ & $7.7 \%$ \\
Other & $\mathbf{6 8 5 , 7 2 4}$ & $\mathbf{4 5 , 7 8 7}$ \\
Total (n) & & \\
\hline Frisk Percentage & $53.2 \%$ & $56.0 \%$ \\
Black & $7.4 \%$ & $6.3 \%$ \\
Black-Hispanic & $26.0 \%$ & $20.5 \%$ \\
White-Hispanic & $7.2 \%$ & $10.1 \%$ \\
White & $6.2 \%$ & $7.1 \%$ \\
Other & $\mathbf{3 8 1 , 7 0 4}$ & $\mathbf{3 0 , 3 4 5}$ \\
Total (n) & & \\
\hline Search Percentage & $50.6 \%$ & $50.6 \%$ \\
Black & $7.0 \%$ & $7.7 \%$ \\
Black-Hispanic & $25.9 \%$ & $24.5 \%$ \\
White-Hispanic & $9.8 \%$ & $10.4 \%$ \\
White & $6.7 \%$ & $6.8 \%$ \\
Other & $\mathbf{5 8 , 3 6 3}$ & $\mathbf{7 , 2 8 3}$ \\
Total (n) & & \\
\hline Arrest Percentage & $51.0 \%$ & $50.0 \%$ \\
Black & $7.3 \%$ & $8.3 \%$ \\
Black-Hispanic & $25.0 \%$ & $25.5 \%$ \\
White-Hispanic & $10.3 \%$ & $10.3 \%$ \\
White & $5.4 \%$ & $5.9 \%$ \\
Other & $\mathbf{4 0 , 8 8 3}$ & $\mathbf{6 , 8 9 8}$ \\
Total (n) & & \\
\hline
\end{tabular}




\section{Stop, Frisk, and Crime in New York City}

In the weeks following the Floyd ruling, city and police department leaders appeared on local and national media, intimating that any changes to the stop-andfrisk program would produce increases in crime. Appearing on NBC's "Meet the Press," for example, former Police Commissioner Kelly said, "No question about it, violent crime will go up." ${ }^{246}$ Table 5 shows trends in violent and property crime rates, as well as overall homicides, in New York City from 2005-2014, and the results refute former Commissioner Kelly's claim. Violent crime rates continued a slow decline from 2005 to 2009 (from 67.3 to 55.2 per 10,000 residents), before increasing through 2012 (63.9). Interestingly, this slight uptick in violent crime occurred during the peak years of stop-and-frisk (2010-2011). Violent crime rates then declined slightly in 2013 and 2014 (62.4 and 59.7 per 10,000 residents, respectively), as the use of stop-and-frisk dropped off precipitously. Property crime rates followed a nearly identical pattern. The trends in overall homicide directly contradict any claim that reduced use of stop-and-frisk caused an increase in violence in New York. In 2011, there were 515 homicides. In 2013 and 2014, there were 335 and 333, respectively - a 35\% decline. ${ }^{247}$ In short, there is no evidence to suggest that reforms to stop-and-frisk compromised the NYPD's ability to effectively fight crime.

\footnotetext{
246 Amanda Terkel, Ray Kelly on Stop-and-Frisk: 'No Question' Violent Crime Will Rise If Program Is Stopped, Huffington Post (Aug. 18, 2013), http://www.huffingtonpost.com/2013/08/18/ray-kelly-stop-and-frisk_n_3776035.html.

247 From 2011 to 2014, New York City's population increased from 8,211,875 to 8,473,938. Uniform Crime and Reporting, Offenses Known to Law Enforcement by City: New York (2011-2014), FED. BuREAU OF INVESTIGATION:

2011: https://ucr.fbi.gov/crime-in-the-u.s/2011/crime-in-the-u.s.2011/tables/table8statecuts/table_8_offenses_known_to_law_enforcement_new_york _by_city_2011.xls

2014: https://www.fbi.gov/about-us/cjis/ucr/crime-in-the-u.s/2014/crime-in-the-u.s.2014/tables/table-8/table-8-bystate/Table_8_Offenses_Known_to_Law_Enforcement_by_New_York_by_City_2014.xls
} 
Table 5. Crime Trends in New York City, 2005-2014 248

\begin{tabular}{|c|c|c|c|c|c|c|c|c|c|c|}
\hline & $\mathbf{2 0 0 5}$ & $\mathbf{2 0 0 6}$ & $\mathbf{2 0 0 7}$ & $\mathbf{2 0 0 8}$ & $\mathbf{2 0 0 9}$ & $\mathbf{2 0 1 0}$ & $\mathbf{2 0 1 1}$ & $\mathbf{2 0 1 2}$ & $\mathbf{2 0 1 3}$ & $\mathbf{2 0 1 4}$ \\
\hline $\begin{array}{c}\text { Violent } \\
\text { Crime }\end{array}$ & 67.3 & 63.8 & 61.4 & 58.0 & 55.2 & 58.2 & 62.4 & 63.9 & 62.4 & 59.7 \\
\hline $\begin{array}{c}\text { Property } \\
\text { Crime }\end{array}$ & 200.2 & 187.9 & 181.9 & 179.7 & 169.0 & 167.5 & 171.0 & 172.2 & 169.1 & 160.2 \\
\hline $\begin{array}{c}\text { Total } \\
\text { Homicides }\end{array}$ & 539 & 596 & 496 & 523 & 471 & 536 & 515 & 419 & 335 & 333 \\
\hline
\end{tabular}

\section{DISCUSSION AND CONCLUSION}

The last 40 years have arguably been the most innovative in the history of policing. ${ }^{249}$ Since the mid-1970s, a host of new strategies have emerged on the law enforcement landscape, from problem-oriented policing (POP) and communityoriented policing (COP), to hot spots policing, focused deterrence/pulling levers (e.g., targeted offender strategies), intelligence-led policing, and even predictive policing. The innovation in strategies has been matched by the development of new technologies such as geographic information systems (GIS), crime analysis and advanced analytics, CompStat, DNA and forensics, license plate readers, lesslethal alternatives (pepper spray, TASER), body-worn cameras, and gunshot

248 Uniform Crime and Reporting, Offenses Known to Law Enforcement by City: New York (2005-2014), FED. BUREAU OF INVESTIGATION:

2005: https://www2.fbi.gov/ucr/05cius/data/table_08_ny.html

2006: https://www2.fbi.gov/ucr/cius2006/data/table_08_ny.html

2007: https://www2.fbi.gov/ucr/cius2007/data/table_08_ny.html

2008: https://www2.fbi.gov/ucr/cius2008/data/table_08_ny.html

2009: https://www2.fbi.gov/ucr/cius2009/data/table_08_ny.html

2010: https://www.fbi.gov/about-us/cjis/ucr/crime-in-the-u.s/2010/crime-in-the-u.s.2010/tables/table-8/10tbl08ny.xls

2011: https://ucr.fbi.gov/crime-in-the-u.s/2011/crime-in-the-u.s.2011/tables/table8statecuts/table_8_offenses_known_to_law_enforcement_new_york _by_city_2011.xls

2012: https://www.fbi.gov/about-us/cjis/ucr/crime-in-the-u.s/2012/crime-in-the-u.s.2012/tables/8tabledatadecpdf/table-8-statecuts/table_8_offenses_known_to_law_enforcement_by_new_york_by_city_2012.xls

2013: https://www.fbi.gov/about-us/cjis/ucr/crime-in-the-u.s/2013/crime-in-the-u.s.2013/tables/table-8/table-8-statecuts/table_8_offenses_known_to_law_enforcement_new_york_by_city_2013.xls

2014: https://www.fbi.gov/about-us/cjis/ucr/crime-in-the-u.s/2014/crime-in-the-u.s.2014/tables/table-8/table-8-bystate/Table_8_Offenses_Known_to_Law_Enforcement_by_New_York_by_City_2014.xls

249 White \& Fradella, supra note 2, at ch. 6. 
detection systems. ${ }^{250}$ During this period of innovation, stop-and-frisk has emerged as a preferred tactic for controlling crime and disorder.

Despite the tremendous innovation in policing, one phenomenon that has remained unchanged is the undercurrent of racial injustice. The misuse and abuse of stop-and-frisk appears to be the next iteration of that injustice. The stories of stop-and-frisk in Newark, Philadelphia, Chicago, Pittsburgh, and New York illustrate that Williams and Murphy's "minority view" of policing remains a stark reality. The deaths of Eric Garner, Michael Brown, and Freddie Gray, among others, demonstrate the centrality of stop-and-frisk to the persistent racial crisis in policing. These tragic deaths have led to unprecedented attention on racial disparities in police actions, best exemplified by the President's Task Force on 21st Century Policing, ${ }^{251}$ and they have facilitated a national dialogue on the need for police accountability and reform.

As part of this dialogue, federal civil litigation has received considerable attention as a potential mechanism for police reform. Federal civil litigation can be employed through a variety of mechanisms, such as individual or class-action $\S$ 1983 lawsuits and U.S. Department of Justice actions via § 14141. Unfortunately, very little research has examined the impact of federal civil litigation on unconstitutional police practices, and as a result, there is little understanding of its effectiveness (or lack thereof) as an instrument of police reform.

\section{A. Federal Civil Litigation and Police Reform in New York}

The current study examines the New York City confluence of racial injustice in policing, misuse of stop-and-frisk by officers, and federal civil litigation designed to precipitate police reform. The results provide direct evidence of the impact of federal civil litigation on unconstitutional stop-and-frisk practices in New York specifically, as well as some more general insights on the potential for federal civil litigation to generate police reform.

The year-to-year comparison of stop-and-frisk in New York highlights a number of positive findings, suggesting that the federal civil litigation has begun to alter the unconstitutional practices outlined in the Floyd case. First, the sheer number of stops conducted by officers has dropped dramatically, by more than $90 \%$. Second, the geographic concentration of stops in mostly minority precincts has also declined. An examination of ten precincts with large minority populations showed that the racial/ethnic concentration of stops has dropped by nearly $10 \%$ overall in those precincts, with some precincts experiencing declines of $50 \%$ or more. Third, stops appear to be more efficient and accurate. The percentage of stops resulting in arrest has more than doubled. The percentage of stops where weapons and contraband were seized remain low but those percentages have

\footnotetext{
250 White \& Fradella, supra note 2, at ch. 6.

251 PREsident's TASK ForCE ON 21st Century Policing, supra note 19.
} 
doubled or tripled compared to the 2011 rates. In short, the NYPD has altered its day-to-day practices with regard to stop-and-frisk, to the benefit of thousands of New Yorkers. And importantly, the reforms in the NYPD's stop-and-frisk program coincided with continued declines in crime and violence in New York, especially homicides which declined by 35\% from 2011 to 2014.

The one negative finding is the persistence of racial disparities in those subjected to stop-and-frisk: minorities remain overrepresented among those stopped, frisked, searched, and arrested by the NYPD. According to the 2010 Census Bureau, the racial and ethnic composition of New York City is approximately 33.3\% White, 22.8\% Black, 28.6\% Hispanic, $12.6 \%$ Asian, and $2.7 \%$ "other." ${ }^{252}$ In 2014, the percentage of Whites, Blacks, and Hispanics (combining Black-Hispanic with White-Hispanic) stopped was $11.9 \%, 53.1 \%$, and $27.3 \%$, respectively. The authors acknowledge that the racial composition of a population is a rough, at best, benchmark for assessing racial disparities. Other benchmarks, such as the racial composition of the arrestee population in New York, would suggest much smaller racial disparities. ${ }^{253}$ Nevertheless, the stability in race/ethnicity among those who were stopped in 2011 and in 2014 is troubling, given that the federal court determined that the NYPD was engaged in unconstitutional stop-and-frisks in 2011. Notably, the persistence of racial disparities in New York is consistent with findings from the few studies that have examined the impact of consent decrees on discriminatory police practices in other jurisdictions (e.g., New Jersey and Los Angeles). ${ }^{254}$

It is clear that more work needs to be done in New York, but this fact should not overshadow the considerable progress that the NYPD has made during the last few years. And importantly, the structure for effective police reform in New York is in place. For example, recent changes have been made to training and policy. The 2015 student guide for patrol recruits presents officers with a more inclusive understanding of diversity issues:

As police officers, you are required to enforce the law impartially without regard to actual or perceived race, class, ethnicity, culture, religion, age, gender, sexual orientation, disability, immigration or housing status. At the same time, we are members of a larger society in which bias and discrimination against certain groups of people are matters of historical and statistical fact. . . . As noted in a recent speech by Police Commissioner Bratton, American policing has been part of the

\footnotetext{
252 U.S. Census Bureau, Profile of General Housing Characteristics: 2010, New York CITY, NEW YORK, http://factfinder.census.gov/faces/tableservices/jsf/pages/productview.xhtml?src=bkmk.

253 Greg Ridgeway, Analysis of Racial Disparities in the New York Police DePARTMENT'S STOP, QUESTION, AND FRISK PRACTICES xii (2007), http://www.rand.org/content/dam/rand/pubs/technical_reports/2007/RAND_TR534.pdf.

254 Kupferberg, supra note 200; STONE, FOGLESONG \& COLE, supra note 202.
} 
best of American history, but unfortunately some of the worst parts as well. Understanding this history and how it has shaped perceptions will help you become a better, more effective police officer. ${ }^{255}$

The NYPD is also in the process of revising the Patrol Guide to provide clearer, more accurate guidance on the proper legal standards for stop-and-frisk, including:

(1) ... what constitutes a stop, when a stop may be conducted, when a frisk may be conducted, and when a search may be conducted;

(2) ... a definition of "reasonable suspicion," the standard needed for a stop based on Terry v. Ohio;

(3) . . . that officers must have separate reasonable suspicion that a person is armed and dangerous in order to conduct a frisk of that person;

(4) require[ing] officers to document the stop and reasonable suspicion, and, if conducted, the frisk, on both a stop report form (formerly called a UF-250) and in their activity logs;

(5) require[ing] supervisory review of stops, including review of the constitutionality of the stop, not just that a stop report form was filled out; and

(6) provid[ing] for supervisors to identify officers needing further training and/or potential discipline. ${ }^{256}$

Last, the federal monitor reviews NYPD activities, analyzes data, and issues public reports with recommendations for change. The monitor's reports can document progress, but they can also highlight deficiencies in supervision, policy, and training. The reporting of deficiencies provides a roadmap for continued reform, and the public nature of this reporting places tremendous pressure on the NYPD to follow that roadmap and address the identified deficiencies. In sum, the findings presented here show that the NYPD has made significant progress since 2011, and the proper mechanisms are in place to ensure that the department will continue to move toward widespread constitutional policing.

\footnotetext{
255 First Report of the Independent Monitor at 36, Floyd v. City of New York, 08-cv-01034AT (S.D.N.Y. July 9, 2015), http://nypdmonitor.org/wpcontent/uploads/2015/08/MonitorsFirstReport-AsFiledInFloydDocket.pdf.

256 Final Recommendations Regarding Patrol Guide 212.11 and Patrol Guide 203.25 at 3, Floyd v. City of New York, 08-cv-01034-AT (S.D.N.Y. Aug. 24, 2015), http://nypdmonitor.org/wpcontent/uploads/2015/09/Revision-to-Stop-and-Frisk-Preventing-Racial-Profiling-Preventing-RacialProfiling-212-211.pdf.
} 


\section{B. Larger Lessons for Federal Civil Litigation as an Instrument for Police Reform}

The federal court litigation in New York was relatively unique. Since the case was filed as a $\S 1983$ class-action lawsuit, plaintiffs first had to satisfy the four requirements for class certification under Federal Rule of Civil Procedure 23(b)(2), namely numerosity, commonality, typicality, and adequacy. ${ }^{257}$ Then plaintiffs were required to demonstrate Fourth and Fourteenth Amendment liability for the certified class as a result of the NYPD's stop-and-frisk program. Margeson highlighted the power of this federal civil litigation approach:

Politics, socio-economic inequality, and the accumulation of precedent that has diminished the likelihood of legal redress for Fourth and Fourteenth Amendment violations have effectively deregulated police power to conduct investigative Terry stops. The Floyd litigation demonstrates the immense value of judicial process to advocates of social reform, especially where the prospective beneficiaries have been underserved by the democratic process. In Floyd, the democratic and judicial processes worked in tandem to effect a policy shift in the oversight of police conduct that either branch, acting in isolation, most probably would not have achieved. ${ }^{258}$

Though the Floyd case began as a class-action suit in 2008, the judge's ruling in 2013 mimicked the oversight process outlined in $\S 14141$. As a result, the progress made by the NYPD in the three years since the Floyd ruling speaks directly to the potential for $\S 14141$ consent decrees to effect change in police departments. Only a handful of studies have sought to assess the effectiveness of $\S$ 14141 consent decrees on law enforcement agencies engaged in pattern or practice unconstitutional policing. The research is mixed, but there are modestly promising findings from that small body of work (e.g., enhanced public satisfaction, implementation of new processes and policies, reductions in use of force and citizen complaints during the consent decree, and greater transparency via access to department data and independent monitor reports). ${ }^{259}$ More generally, the experiences of agencies under $\S 14141$ consent decrees demonstrate that police reform is a complex, multi-year process with a high level of difficulty. It involves organizational change in a profession characterized by resistance to change, and the remedies target functions that go to the very core of policing: supervision, training, policy, and accountability. In short, police reform is a marathon, not a

\footnotetext{
257 See Floyd v. City of New York, 283 F.R.D. 153, 160 (S.D.N.Y. 2012) (class certification opinion); see also Margeson, supra note 174, at 756-64.

258 Margeson, supra note 174, at 771-72.

259 See Chanin, supra note 203; Chanin, supra note 204; DAVIS, HENDERSON \& OrTIZ, supra note 199; Kupferberg, supra note 200; STONE, FogLesong \& COLE, supra note 202.
} 
sprint. The results from this study demonstrate that important police reforms can be achieved early on during the marathon, as a result of federal civil litigation. 